\title{
Electronic communication in oligonuclear ferrocene complexes with anionic four-coordinate boron bridges $\dagger$
}

\author{
Linda Kaufmann, ${ }^{a}$ Jens-Michael Breunig, ${ }^{a}$ Hannes Vitze, ${ }^{a}$ Frauke Schödel, ${ }^{a}$ Israel Nowik, ${ }^{b}$ Markus Pichlmaier, ${ }^{c}$ \\ Michael Bolte, ${ }^{a}$ Hans-Wolfram Lerner, ${ }^{a}$ Rainer F. Winter, ${ }^{c}$ Rolfe H. Herber ${ }^{b}$ and Matthias Wagner*a
}

\begin{abstract}
The di- and trinuclear ferrocene species $\mathrm{Li}\left[\mathrm{Fc}-\mathrm{BPh}_{2}-\mathrm{Fc}\right](\mathrm{Li}[9])$ and $\mathrm{Li}_{2}\left[\mathrm{Fc}-\mathrm{BPh}_{2}-\mathrm{fc}_{-}-\mathrm{BPh}_{2}-\mathrm{Fc}\left(\mathrm{Li}_{2}[\mathbf{1 0}]\right)\right.$ have been investigated with regard to their electrochemical properties and the degree of intervalence charge-transfer after partial oxidation. Li[9] shows two distinct one-electron redox waves for its chemically equivalent ferrocenyl substituents in the cyclic voltammogram $\left(E_{1 / 2}=-0.38 \mathrm{~V},-0.64 \mathrm{~V} ; v s\right.$. $\mathrm{FcH} / \mathrm{FcH}^{+}$). The corresponding values of $\mathrm{Li}_{2}[10]$ are $E_{1 / 2}=-0.45 \mathrm{~V}$ (two-electron process) and $-1.18 \mathrm{~V}$. All these redox events are reversible at $r$. t. on the time scale of cyclic voltammetry. X-ray crystallography on the mixed-valent $\mathrm{Fe}_{2}{ }_{2} \mathrm{Fe}^{\mathrm{III}}$ complex $\mathrm{Li}(12-\mathrm{c}-4)_{2}[10]$ reveals the centroid-centroid distance between the cyclopentadienyl rings of each of the terminal ferrocenyl substituents $(3.329 \AA)$ to be significantly smaller than in the central $1,1^{\prime}$-ferrocenediyl fragment $(3.420 \AA)$. This points towards a charge-localized structure (on the time scale of X-ray crystallography) with the central iron atom being in the $\mathrm{Fe}^{\mathrm{III}}$ state. Mößbauer spectroscopic measurements on $\mathrm{Li}(12-\mathrm{c}-4)_{2}[10]$ lend further support to this interpretation. Spectroelectrochemical measurements on $\mathrm{Li}[9]$ and $\mathrm{Li}_{2}[10]$ in the wavelength range between 300-2800 $\mathrm{nm}$ do not show bands interpretable as intervalence charge-transfer absorptions for the mixed-valent states. All data accumulated so far lead to the conclusion that electronic interaction between the individual $\mathrm{Fe}$ atoms in $\mathrm{Li}[\mathbf{9}]$ and $\mathrm{Li}_{2}[10]$ occurs via a through-space pathway and/or is electrostatic in nature.
\end{abstract}

\section{Introduction}

Poly(ferrocenylene)s A (Fig. 1) represent an important class of processable metal-containing polymers with applications ranging from molecular electronics to the preparation of magnetic ceramics. ${ }^{1-4}$ The materials properties of macromolecules $\mathbf{A}$ depend to a large extent on the nature of the bridging element $\mathrm{ER}_{\mathrm{x}}$, which can be varied over a broad range (e.g. $\mathrm{ER}_{\mathrm{x}}=\mathrm{SiMe}_{2},{ }^{5} \mathrm{Sn}^{\prime} \mathrm{Bu}_{2},{ }^{6}$ $\left.\mathrm{PPh},{ }^{7} \mathrm{~S}^{8}\right)$. For the following reasons, our group is particularly interested in boron-bridged poly(ferrocenylene)s: ${ }^{9}$ (i) Three-coordinate boron atoms $\left(\mathrm{ER}_{\mathrm{x}}=\mathrm{BR}^{\prime}\right)$ possess an empty $p$-orbital that is wellsuited for $\pi$-conjugation with the cyclopentadienyl rings and thus able to act as an efficient transmitter of electronic interactions between the individual $1,1^{\prime}$-ferrocenediyl moieties. ${ }^{10,11}$ (ii) Fourcoordinate boron atoms $\left(\mathrm{ER}_{\mathrm{x}}=\mathrm{BR}_{2}^{\prime}\right)$ can bear a positive, a negative, or zero charge which provides a powerful set-screw for tuning the $\mathrm{Fe}^{\text {II }} / \mathrm{Fe}^{\mathrm{III}}$ redox potentials of corresponding ferrocene oligomers by electrostatic means. ${ }^{12,13}$ (iii) The formation of $\mathrm{B}-\mathrm{L}$

"Institut für Anorganische Chemie, Goethe-Universität Frankfurt, Maxvon-Laue-Strasse 7, 60438, Frankfurt (Main), Germany. E-mail: Matthias.Wagner@chemie.uni-frankfurt.de

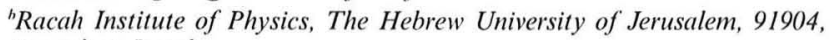
Jerusalem, Israel

'Institut für Anorganische Chemie, Universität Regensburg, Universitätsstrasse 31, 93040, Regensburg, Germany

† Electronic supplementary information (ESI) available: Experimental details. CCDC reference numbers 699649 (3), 699647 (6), 699646 (7), $699650\left((\mathrm{Li}(12-\mathrm{c}-4)(\mathrm{THF}))_{2}[10]\right), 699648\left(\mathrm{Li}(12-\mathrm{c}-4)_{2}[10]\right)$ and 710783 $\left(\mathrm{Li}(\mathrm{THF})_{4}[\mathbf{1 1}]\right)$. For ESI and crystallographic data in CIF or other electronic format see DOI: $10.1039 /$ b821406a adducts between poly(ferrocenylene)s with three coordinate boron bridges and Lewis bases (L) influences the degree of electronic communication along the polymer backbone, thereby offering an opportunity to design novel sensor compounds and switchable nanowires.

Given this background, a thorough evaluation of the degree of ferrocene-ferrocene interaction via three- and four-coordinate boron linkers and a comprehension of the underlying transmission pathways is essential for further rational developments in this area. We have already reported evidence for pronounced electronic communication along the chains of A-type polymers in which $\mathrm{ER}_{\mathrm{x}}$ equals $\mathrm{BMes}^{10}$ or $\mathrm{BO}\left(\mathrm{CH}_{2}\right)_{4} \mathrm{Br}^{11}$ (Mes = mesityl). There is also a strong indication for charge-transfer interactions between ferrocene and $\pi^{*}$-orbitals of the 4,4'-bipyridyl units in polymeric B-N adducts B (Fig. 1) even though the boron atoms are four-coordinate. ${ }^{14-17}$ The electronic structure, photophysics, and relaxation dynamics of charge-transfer excited states in soluble model systems of type $[\mathrm{C}]\left(\mathrm{PF}_{6}\right)_{2}$ (Fig. 1) have been investigated using cyclic voltammetry, spectroelectrochemistry and laser spectroscopy. ${ }^{18}$ These results led to the conclusion that a fourcoordinate boron atom is not necessarily an insurmountable barrier to electronic interactions between its redox-active substituents.

This conclusion is further substantiated by the fact that two different redox potentials are observed for the $\mathrm{Fe}^{\mathrm{Il}} / \mathrm{Fe}^{\mathrm{III}}$ transitions in dinuclear complexes like Li[D] (Fig. 1) even though the two ferrocenyl substituents are chemically equivalent. ${ }^{12,13}$

Most importantly in this context, a broad band with a maximum near $\lambda=2200 \mathrm{~nm}$ has been reported to appear in the UV/vis/NIR spectrum of the related ferricenyltris(ferrocenyl)borate zwitterion 


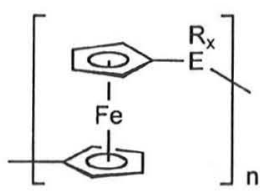

A
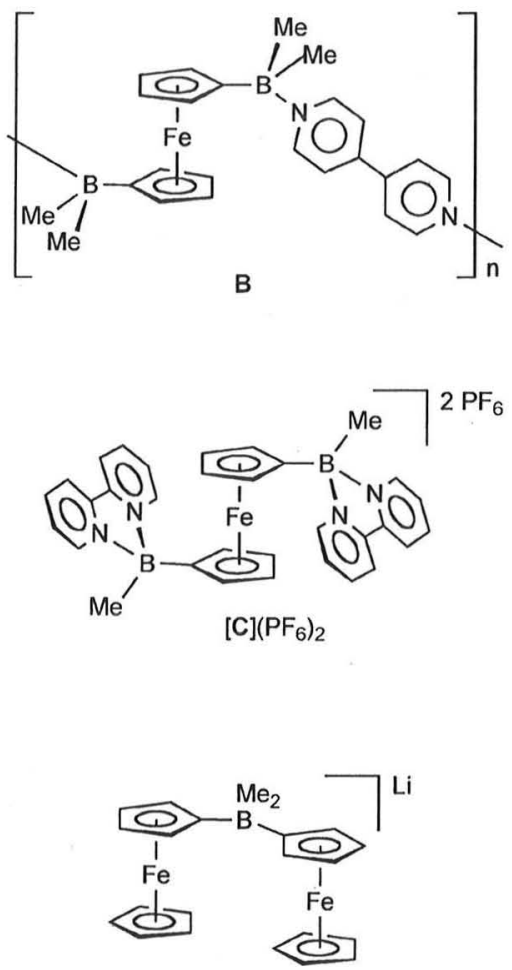

$\mathrm{Li}[\mathrm{D}]$

Fig. 1 General representation of $\mathrm{ER}_{\mathrm{x}}$-bridged poly(ferrocenylene)s $\mathbf{A}$; coordination polymer $\mathbf{B}$ showing charge-transfer interactions between the ferrocenylene fragments and the 4,4'-bipyridyl bridge; $[\mathrm{C}]\left(\mathrm{PF}_{6}\right)_{2}$, a soluble model system of $\mathbf{B}$; dinuclear $\mathrm{BMe}_{2}$-bridged complex $\mathrm{Li}[\mathbf{D}]$ possessing two different $\mathrm{Fe}^{\mathrm{II}} / \mathrm{Fe}^{\mathrm{III}}$ redox potentials.

$\left(\left[\mathrm{Fc}^{\mathrm{III}}\left(\mathrm{Fc}^{\mathrm{II}}\right)_{3} \mathrm{~B}\right]\right)$ and was interpreted as intervalence charge-transfer absorption $\left(\mathrm{Fc}=\left(\mathrm{C}_{5} \mathrm{H}_{5}\right) \mathrm{Fe}\left(\mathrm{C}_{5} \mathrm{H}_{4}\right)\right) .{ }^{19}$ The question thus arises whether the electrochemical behaviour of Li[D]-type oligoferrocenes is merely governed by electrostatic interactions or whether charge delocalization also plays a significant role. In addition to $\mathrm{Li}[\mathbf{D}]$, our group has recently published the synthesis and structural characterization of its trinuclear congener $\mathrm{Li}_{2}\left[\mathrm{Fc}-\mathrm{BMe}_{2}-\right.$ fc-BMe $-\mathrm{Fc}$ ( $\left(\mathrm{fc}=\left(\mathrm{C}_{5} \mathrm{H}_{4}\right)_{2} \mathrm{Fe}\right) \cdot{ }^{13}$ Unfortunately, both compounds tend to decompose upon iron oxidation, so that cyclic voltammograms had to be recorded at $-78^{\circ} \mathrm{C}$ and all efforts regarding the isolation of mixed-valent species were unsuccessful.

Given the apparent stability of $\left[\mathrm{Fc}^{\mathrm{II}}\left(\mathrm{Fc}^{\mathrm{II}}\right)_{3} \mathrm{~B}\right]$, we postulated that replacement of the methyl substituents by phenyl groups in $\mathrm{Li}\left[\mathrm{Fc}-\mathrm{BMe}_{2}-\mathrm{Fc}\right](\mathrm{Li}[\mathrm{D}])$ and $\mathrm{Li}_{2}\left[\mathrm{Fc}-\mathrm{BMe}_{2}-\mathrm{fc}-\mathrm{BMe}_{2}-\mathrm{Fc}\right]$ will lead to increased stability and thus allow us to assess the level of electronic communication between the redox-active sites in greater detail. The results of our studies on $\mathrm{Li}\left[\mathrm{Fc}-\mathrm{BPh}_{2}-\mathrm{Fc}\right]$ (Li[9]; Scheme 2) and $\mathrm{Li}_{2}\left[\mathrm{Fc}-\mathrm{BPh}_{2}-\mathrm{fc}-\mathrm{BPh}_{2}-\mathrm{Fc}\right]\left(\mathrm{Li}_{2}[\mathbf{1 0}] ;\right.$ Scheme 2$)$ a re outlined in this paper.

\section{Results and discussion}

\section{Synthesis and NMR spectroscopy}

Compounds $\mathrm{Li}\left[\mathrm{Fc}-\mathrm{BMe}_{2}-\mathrm{Fc}\right](\mathrm{Li}[\mathrm{D}])$ and $\mathrm{Li}_{2}\left[\mathrm{Fc}-\mathrm{BMe}_{2}-\mathrm{fc}-\mathrm{BMe}_{2}-\right.$ $\mathrm{Fc}$ ] are readily accessible via $\mathrm{B}-\mathrm{C}$ adduct formation between $\mathrm{FcBMe}_{2}$ and $\mathrm{FcLi}$ or $1,1^{\prime}-\mathrm{fcLi}_{2} \times 2 / 3$ TMEDA. ${ }^{13}$ We therefore considered the corresponding diphenylborylferrocenes 3 and 6 (Scheme 1) useful building blocks for the synthesis of $\mathrm{BPh}_{2}$-bridged oligo- and polyferrocenes. $\mathrm{FcBPh}_{2}(3)$ has already been prepared in the form of a red oil by Herberhold and Wrackmeyer, who treated $\mathrm{FcLi}$ with $\mathrm{MeOBPh}_{2}{ }^{20}{ }^{20} \mathrm{In}$ our hands, the reaction between $\mathrm{FcHgCl}(1)^{21}$ and $\mathrm{BrBPh}_{2}(2)^{22}$ resulted in better yields and higher purity of 3 .

The $1,1^{\prime}$-diborylated derivative 6 is not known in the literature so far, and its preparation turned out to be cumbersome. A synthesis approach analogous to the preparation of $\mathbf{3}$ is not practical due to the poor solubility of the doubly mercurated ferrocene $1,1^{\prime}$ $\mathrm{fc}(\mathrm{HgCl})_{2}$. The following potential alternative routes resulted in inseparable product mixtures rather than in the formation of pure 6: (i) $1,1^{\prime}-\mathrm{fc}\left(\mathrm{BBr}_{2}\right)_{2}$ and $\mathrm{PhLi}$ or $\mathrm{SnPh}_{4}$ or $\mathrm{PhSiMe}_{3}$, (ii) $1,1^{\prime}$ fc $\left(\mathrm{B}(\mathrm{OMe})_{2}\right)_{2}$ and $\mathrm{PhLi}$, (iii) $1,1^{\prime}-\mathrm{fcLi}_{2} \times 2 / 3 \mathrm{TMEDA}$ and $\mathrm{XBPh}_{2}$ (X $=\mathrm{Br}$, $\left.\mathrm{O}^{\prime} \mathrm{Pr}\right)$, (iv) $\mathrm{Li}_{2}\left[1,1^{\prime}-\mathrm{fc}\left(\mathrm{BPh}_{3}\right)_{2}\right]$ and $\mathrm{ClSiMe}_{3}$. We were finally able to synthesize 6 from $1,1^{\prime}-\mathrm{fcLi}_{2} \times 2 / 3$ TMEDA (4) and 2 equiv. of $\mathrm{MeOBPh}_{2}$, however, the target compound was contaminated with substantial amounts of $\mathrm{Li}(\mathrm{TMEDA})\left[\mathrm{MeOBPh}_{3}\right]$ (7; Scheme 1). Both components precipitated from hexane as single crystals. Since it was not possible to completely separate the two products by fractional crystallization, we had to rely on manual crystal selection in order to obtain samples of reasonable purity for NMR-spectroscopic characterization.

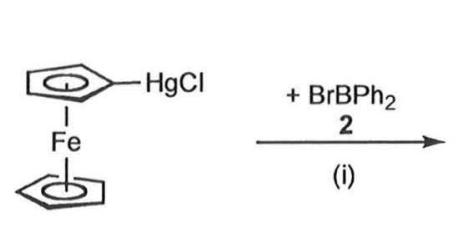

1

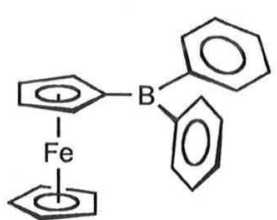

3

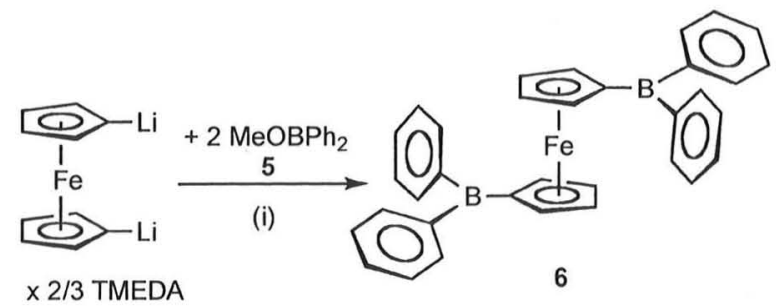

4

+ $\mathrm{Li}(\mathrm{TMEDA})\left[\mathrm{MeOBPh}_{3}\right]$

7

Scheme 1 Synthesis of the borylated ferrocenes 3 and 6. (i) hexane, $-78^{\circ} \mathrm{C}$ to r. t. 
The dinuclear $\mathrm{BPh}_{2}$-bridged compound $\mathrm{Li}[9]$ is readily accessible from $\mathrm{Fc}_{2} \mathrm{BBr}$ (8) and 2 equiv. of $\mathrm{PhLi}$ (Scheme 2). Details of the synthesis protocol as well as an X-ray crystal structure determination of $\mathrm{Li}\left(\mathrm{OBu}_{2}\right)[9]$ have already been published elsewhere. ${ }^{23}$ Attempts at the synthesis of the $\mathrm{Fe}^{\mathrm{II}} \mathrm{Fe}^{\mathrm{III}}$ mixed-valent species 9 by reaction of $\mathrm{Li}[9]$ with $\mathrm{AgBF}_{4}, \mathrm{AgPF}_{6}$ or $\mathrm{I}_{2}$, always resulted in the formation of a red-brown oil that could not be transformed into an analytically pure solid. However, the UV/vis spectra of chemically oxidized Li[9] proved to be identical to the spectrum obtained during electrochemical oxidation of this compound (see below). Due to its paramagnetic nature, interpretable NMR spectra of 9 could not be acquired.
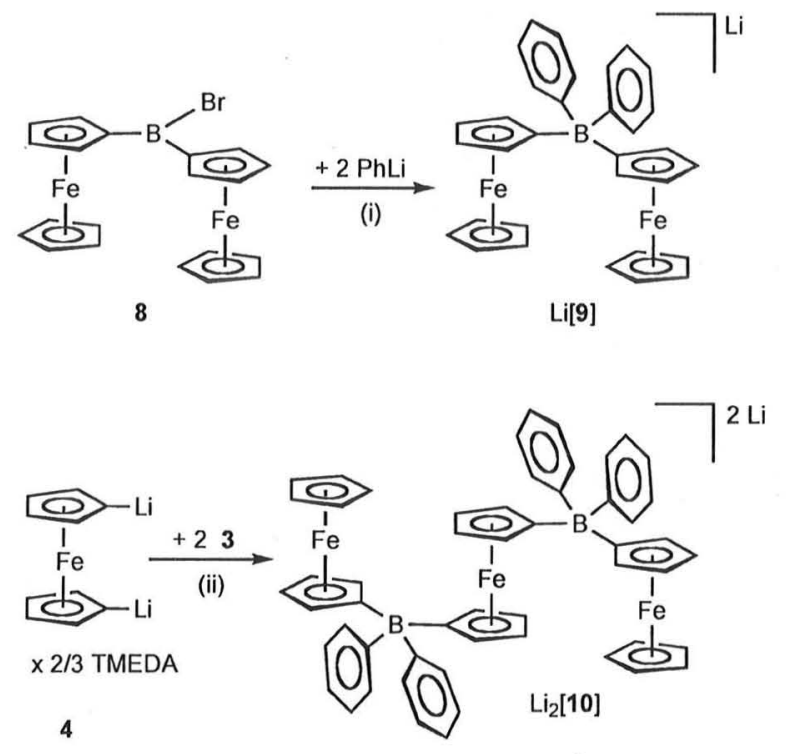

(iii) $\downarrow+\mathrm{O}_{2}$

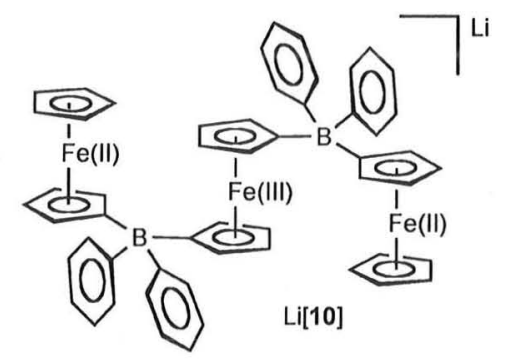

Scheme 2 Synthesis of the di- and trinuclear $\mathrm{BPh}_{2}$-bridged ferrocene aggregates $\mathrm{Li}[9]$ and $\mathrm{Li}_{2}[\mathbf{1 0}]$; oxidation of $\mathrm{Li}_{2}[\mathbf{1 0}]$ to its mixed-valent state $\mathrm{Li}[10]$. (i) toluene $/ \mathrm{OBu}_{2},-78{ }^{\circ} \mathrm{C}$ to r. t.; (ii) $\mathrm{THF},-78{ }^{\circ} \mathrm{C}$ to r. t.; (iii) $\mathrm{THF}$, r. $\mathrm{t}$.

The trinuclear species $\mathrm{Li}_{2}[\mathbf{1 0}]$ is formed from 2 equiv. of $\mathrm{FcBPh}_{2}$ (3) and 1, $1^{\prime}-\mathrm{fcLi}_{2} \times 2 / 3$ TMEDA (4) ${ }^{24,25}$ under mild conditions and in good yields. In the presence of trace amounts of oxygen, $\mathrm{Li}_{2}[10]$ is immediately transformed into its mixed-valent state $\mathrm{Li}[10]$ (Scheme 2). $\mathrm{Li}_{2}[10]$ and $\mathrm{Li}[10]$ crystallized from $\mathrm{THF} /$ hexane in the presence of crown ether (12-c-4) as ether adducts ( $\mathrm{Li}(12-\mathrm{c}-$ 4)(THF) $)_{2}[10]$ and $\operatorname{Li}(12-\mathrm{c}-4)_{2}[10]$, respectively.

For reasons of comparison, we decided to revisit the ferricenyltris(ferrocenyl)borate inner salt $\left[\mathrm{Fc}^{\mathrm{III}}\left(\mathrm{Fc}^{\mathrm{II}}\right)_{3} \mathrm{~B}\right]^{19}(\mathbf{1 1}$; Scheme 3$)$ and
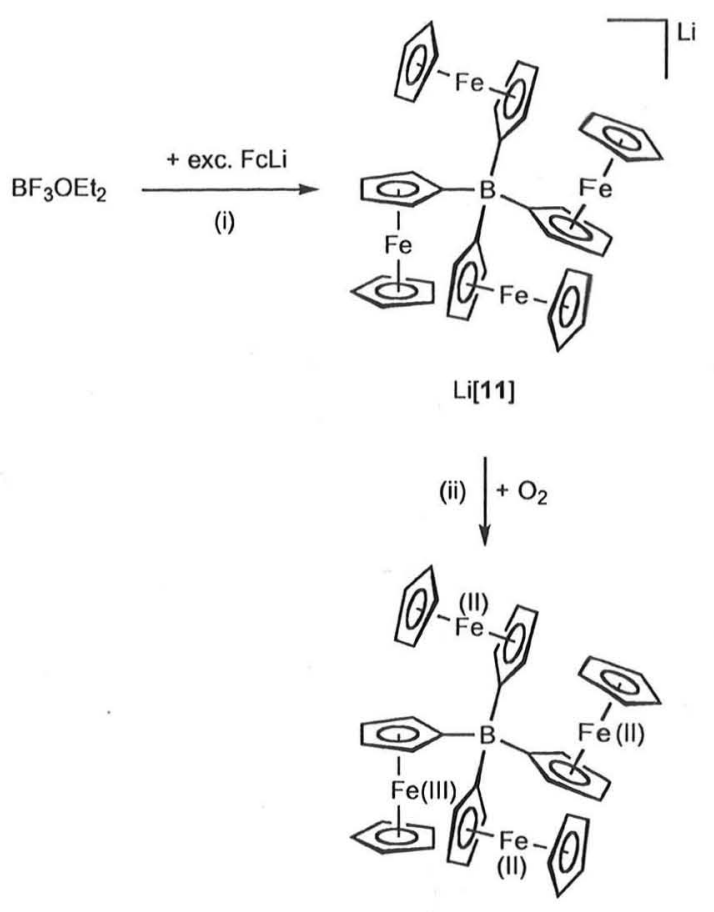

11

Scheme 3 Synthesis of $\mathrm{Li}[\mathbf{1 1}]$; oxidation of $\mathrm{Li}[\mathbf{1 1}]$ to its mixed-valent state 11. (i) $\mathrm{THF} /$ pentane, r. t.; (ii) $\mathrm{CH}_{2} \mathrm{Cl}_{2}$, r. t.

also to synthesize and structurally characterize the fully reduced form $\mathrm{Li}[\mathbf{1 1}]$. $\mathrm{Li}[\mathbf{1 1}]$ is accessible from $\mathrm{BF}_{3} \cdot \mathrm{OEt}_{2}$ and excess $\mathrm{FcLi}$, provided that strictly anaerobic conditions are maintained. Single crystals of $\mathrm{Li}(\mathrm{THF})_{4}[\mathbf{1 1}]$ were grown from $\mathrm{THF} /$ pentane. The targeted oxidation of $\mathrm{Li}(\mathrm{THF})_{4}[11]$ to 11 was performed essentially as described in the literature (Scheme 3). ${ }^{19}$

The NMR data of $3^{20}$ and $\mathrm{Li}[9]^{23}$ are in accord with published values. The "B NMR resonance of $\mathbf{6}$ is broadened beyond detection, probably as a result of slow intramolecular motion (note that already the monosubstituted analog $\mathbf{3}$ shows a very broad signal $\left(h_{1 / 2}=600 \mathrm{~Hz} ; \delta\left({ }^{11} \mathrm{~B}\right)=63.3\right)$. All ${ }^{~} \mathrm{H}$ and ${ }^{13} \mathrm{C}$ NMR resonances of $\mathbf{6}$ are similar to those of $\mathbf{3}$ and therefore do not merit further discussion. The "B NMR spectrum of $\mathrm{Li}_{2}[10]$ is characterized by a signal at $-11.7 \mathrm{ppm}$ which lies in a range typical of four-coordinate boron nuclei. ${ }^{26}$ All proton resonances are broadened at r. t. A hump lacking any fine structure appears in the region of the $\mathrm{C}_{5} \mathrm{H}_{4}$ and $\mathrm{C}_{5} \mathrm{H}_{5}$ signals; the phenyl resonances are better resolved and appear at $6.63 \mathrm{ppm}, 6.79 \mathrm{ppm}$, and $7.35 \mathrm{ppm}$. Similar to $\mathrm{Li}_{2}[\mathbf{1 0}], \mathrm{Li}[\mathbf{1 1}]$ gives rise to a signal at $-15.3 \mathrm{ppm}$ in the "B NMR spectrum. All four ferrocenyl substituents are chemically equivalent $\left(\delta\left({ }^{1} \mathrm{H}\right)=3.69\left(\mathrm{C}_{5} \mathrm{H}_{5}\right), 3.87,4.34\left(\mathrm{C}_{5} \mathrm{H}_{4}\right)\right)$. In the ${ }^{13} \mathrm{C}$ NMR spectrum, both $\mathrm{C}_{5} \mathrm{H}_{4}$ resonances of $\mathrm{Li}[11]$ show a multiplet structure due to partially resolved " $\mathrm{B}$ coupling (the ipso-carbon signal is not observed due to quadrupolar broadening). Similar to $\mathbf{9}$, the paramagnetic nature of $\mathrm{Li}[\mathbf{1 0}]$ and $\mathbf{1 1}$ precluded their characterization by NMR spectroscopy.

\section{Crystal structure determinations}

Selected crystallographic data of $3,6,(\operatorname{Li}(12-\mathrm{c}-4)(\mathrm{THF}))_{2}[10]$, $\mathrm{Li}(12-\mathrm{c}-4)_{2}[\mathbf{1 0}]$, and $\mathrm{Li}(\mathrm{THF})_{4}[11]$ are summarized in Tables 1 
Table 1 Crystallographic data of 3 and 6

\begin{tabular}{lll}
\hline compound & 3 & 6 \\
\hline formula & $\mathrm{C}_{22} \mathrm{H}_{19} \mathrm{BFe}$ & $\mathrm{C}_{34} \mathrm{H}_{28} \mathrm{~B}_{2} \mathrm{Fe}$ \\
fw & 350.03 & 514.03 \\
colour, shape & red, needle & red, needle \\
temperature $(\mathrm{K})$ & $173(2)$ & $173(2)$ \\
crystal system & tetragonal & orthorhombic \\
space group & $P 43$ & $F d d 2$ \\
$a(\AA)$ & $11.2142(7)$ & $18.425(4)$ \\
$b(\AA)$ & $11.2142(7)$ & $30.690(6)$ \\
$c(\AA)$ & $13.5550(11)$ & $9.2970(19)$ \\
$\alpha\left(^{\circ}\right)$ & 90 & 90 \\
$\beta\left({ }^{\circ}\right)$ & 90 & 90 \\
$\gamma\left({ }^{\circ}\right)$ & 90 & 90 \\
$V\left(\AA^{3}\right)$ & $1704.7(2)$ & $5257.1(18)$ \\
$Z$ & 4 & 8 \\
$D_{\text {calcd. }}\left(\mathrm{g} \mathrm{cm}{ }^{-3}\right)$ & 1.364 & 1.299 \\
$F(000)$ & 728 & 2144 \\
$\mu\left(\mathrm{mm}{ }^{-1}\right)$ & 0.883 & 0.595 \\
crystal size $\left(\mathrm{mm}{ }^{3}\right)$ & $0.24 \times 0.06 \times 0.05$ & $0.24 \times 0.11 \times 0.10$ \\
no. of rflns collected & 21782 & 7049 \\
no. of indep rflns $\left(R_{\text {int }}\right)$ & $3214(0.0716)$ & $2204(0.0758)$ \\
data/restraints/parameters & $3214 / 1 / 217$ & $2204 / 1 / 168$ \\
$\mathrm{GOOF}$ on $F^{2}$ & 1.025 & 1.010 \\
$R 1, w R 2(I>2 \sigma(I))$ & $0.0433,0.1033$ & $0.0372,0.0710$ \\
$R 1, w R 2($ all data) & $0.0486,0.1069$ & $0.0521,0.0788$ \\
largest diff peak and hole $\left(\mathrm{e} \AA^{-3}\right)$ & $0.461,-0.476$ & $0.196,-0.236$ \\
\hline & &
\end{tabular}

and 2; details of the crystal structure analysis of 7 are compiled in the ESI (Fig. 1S, Table 1S $\dagger$ ).

3 (Fig. 2) and 6 (Fig. 3) feature planar three-coordinate boron atoms. In both compounds, the B-Cp bonds are shorter by about $0.04 \AA$ than the $\mathrm{B}-\mathrm{Ph}$ bonds, thereby indicating that the ferrocene fragment acts as a stronger $\pi$-donor than a phenyl ring. The resulting borafulvene character, which also results in a distinctive
C-C bond length alternation within the cyclopentadienyl rings of 3 and $\mathbf{6}$, contributes to the electronic saturation of the electrondeficient boron atoms. In addition to that, there is a second type of interaction in borylated ferrocenes that involves filled $d$-type orbitals at iron and the empty $p$-orbital at boron and manifests itself by a bending of the boryl substituent out of the plane of the cyclopentadienyl ring towards the iron atom. ${ }^{27,28}$ In the cases of 3 and 6 , the corresponding dip angles $\alpha^{*}$ amount to $13.0^{\circ}$ in 3 and $10.8^{\circ}$ in the $C_{2}$-symmetric molecule $6\left(\alpha^{*}=180^{\circ}-\alpha, \alpha=\right.$ $\operatorname{COG}\left(\mathrm{C}_{5} \mathrm{H}_{4}\right)-\mathrm{C}_{i p s s}-\mathrm{B} ; \mathrm{COG}\left(\mathrm{C}_{5} \mathrm{H}_{4}\right)$ : centroid of a cyclopentadienyl ring). As usual, the degree of bending is higher in the monoborylated than in the diborylated species. The $\alpha^{*}$ value of 3 is the same as in $\mathrm{FcBMe}_{2}\left(\alpha^{*}=13.0^{\circ}\right),{ }^{28}$ but it is smaller than the dip angle of $\mathrm{FcBBr}_{2}\left(\alpha^{*}=18.3^{\circ}\right)^{27}$ and $\mathrm{FcB}\left(\mathrm{C}_{6} \mathrm{~F}_{5}\right)_{2}\left(\alpha^{*}=16^{\circ}\right) .{ }^{29}$ No X-ray crystal structure analyses of $1,1^{\prime}-\mathrm{fc}\left(\mathrm{BMe}_{2}\right)_{2}$ or $1,1^{\prime}-\mathrm{fc}\left(\mathrm{B}\left(\mathrm{C}_{6} \mathrm{~F}_{5}\right)_{2}\right)_{2}$ are available to date. We therefore compare 6 with $1,1^{\prime}-\mathrm{fc}(\mathrm{BBrMe})_{2}$ $\left(\alpha^{*}=9.4^{\circ}\right)^{28}$ and $1,1^{\prime}-\mathrm{fc}\left(\mathrm{BBr}_{2}\right)_{2}\left(\alpha^{*}=9.1^{\circ}\right)^{30}$ which reveal a similar degree of ligand bending. The ferrocenyl substituent in $\mathbf{3}$ as well as the $1,1^{\prime}$-ferrocenediyl backbone in $\mathbf{6}$ adopt an eclipsed conformation (3: $\mathrm{C}(1)-\mathrm{COG}(1)-\mathrm{COG}(11)-\mathrm{C}(11)=7.2^{\circ}, 6$ : $\mathrm{C}(1)$ $\operatorname{COG}(1)-\operatorname{COG}(4 \mathrm{~A})-\mathrm{C}(4 \mathrm{~A})=-4.0^{\circ} ; \operatorname{COG}(\mathrm{X})$ : centroid of the cyclopentadienyl ring containing the carbon atom $\mathrm{C}(\mathrm{X})$ ). As a consequence, the torsion angle between the two boryl substituents of 6 has a value of $\mathrm{B}(1)-\mathrm{COG}(1)-\mathrm{COG}(1 \mathrm{~A})-\mathrm{B}(1 \mathrm{~A})=140.9^{\circ}$.

In the solid state, both trinuclear aggregates ( $\mathrm{Li}(12-\mathrm{c}-$ 4)(THF) $)_{2}[10]$ (Fig. 4) and $\operatorname{Li}(12-\mathrm{C}-4)_{2}[10]$ (Fig. 5) possess an inversion centre located at $\mathrm{Fe}(1)$. The $\mathrm{Li}^{+}$ions are wrapped by ether ligands and do not establish short contacts with the anionic molecules. $(\mathrm{Li}(12-\mathrm{c}-4)(\mathrm{THF}))_{2}[\mathbf{1 0}]$ contains two $\mathrm{Li}^{+}$ions per oligoferrocene moiety, whereas in $\operatorname{Li}(12-\mathrm{c}-4)_{2}[10]$ the cation : anion ratio is $1: 1$. This is in accord with the presence of three $\mathrm{Fe}^{\mathrm{II}}$ ions in $(\mathrm{Li}(12-\mathrm{c}-4)(\mathrm{THF}))_{2}[\mathbf{1 0}]$ but points towards two $\mathrm{Fe}^{\mathrm{II}}$ ions and one $\mathrm{Fe}^{\mathrm{III}}$ centre in $\mathrm{Li}(12-\mathrm{c}-4)_{2}[\mathbf{1 0}]$. This conclusion is

Table 2 Crystallographic data of $(\mathrm{Li}(12-\mathrm{c}-4)(\mathrm{THF}))_{2}[10], \mathrm{Li}(12-\mathrm{c}-4)_{2}[10]$ and $\mathrm{Li}(\mathrm{THF})_{4}[11]$

\begin{tabular}{|c|c|c|c|}
\hline compound & $(\mathrm{Li}(12-\mathrm{c}-4)(\mathrm{THF}))_{2}[\mathbf{1 0}]$ & $\operatorname{Li}(12-\mathrm{c}-4)_{2}[10]$ & $\mathrm{Li}(\mathrm{THF})_{4}[\mathbf{1 1}]$ \\
\hline formula & $\mathrm{C}_{78} \mathrm{H}_{94} \mathrm{~B}_{2} \mathrm{Fe}_{3} \mathrm{Li}_{2} \mathrm{O}_{10}$ & $\mathrm{C}_{70} \mathrm{H}_{78} \mathrm{~B}_{2} \mathrm{Fe}_{3} \mathrm{LiO}_{8} \times \mathrm{C}_{4} \mathrm{H}_{8} \mathrm{O}$ & $\mathrm{C}_{56} \mathrm{H}_{68} \mathrm{BFe}_{4} \mathrm{LiO}_{4}$ \\
\hline fw & 1394.58 & 1315.54 & 1046.25 \\
\hline colour, shape & orange, block & brown, needle & red, block \\
\hline temperature $(\mathrm{K})$ & $173(2)$ & $173(2)$ & $173(2)$ \\
\hline crystal system & monoclinic & orthorhombic & monoclinic \\
\hline space group & $P 2_{1} / n$ & Pnma & $P 2_{1} / n$ \\
\hline$a(\AA)$ & $14.9703(10)$ & $17.4879(19)$ & $14.9829(9)$ \\
\hline$b(\AA)$ & $10.3522(6)$ & $27.436(3)$ & $20.0854(10)$ \\
\hline$c(\AA)$ & $22.9360(18)$ & $15.5563(17)$ & $16.7066(9)$ \\
\hline$\alpha\left({ }^{\circ}\right)$ & 90 & 90 & 90 \\
\hline$\beta\left({ }^{\circ}\right)$ & $105.526(5)$ & 90 & $100.813(5)$ \\
\hline$\gamma\left({ }^{\circ}\right)$ & 90 & 90 & 90 \\
\hline$V\left(\AA^{3}\right)$ & $3424.8(4)$ & $7463.9(14)$ & $4938.4(5)$ \\
\hline$Z$ & 2 & 4 & 4 \\
\hline$D_{\text {calcd. }}\left(\mathrm{g} \mathrm{cm}^{-3}\right)$ & 1.352 & 1.171 & 1.407 \\
\hline$F(000)$ & 1472 & 2772 & 2192 \\
\hline$\mu\left(\mathrm{mm}^{-1}\right)$ & 0.687 & 0.626 & 1.198 \\
\hline crystal size $\left(\mathrm{mm}^{3}\right)$ & $0.23 \times 0.21 \times 0.18$ & $0.30 \times 0.12 \times 0.11$ & $0.37 \times 0.33 \times 0.32$ \\
\hline no. of rflns collected & 29466 & 33604 & 30721 \\
\hline no. of indep rfins $\left(R_{\text {int }}\right)$ & $6418(0.1120)$ & $6709(0.1866)$ & $9233(0.0628)$ \\
\hline data/restraints/parameters & $6418 / 48 / 539$ & $6709 / 33 / 378$ & $9233 / 0 / 595$ \\
\hline GOOF on $F^{2}$ & 0.971 & 0.979 & 0.961 \\
\hline$R 1, w R 2(I>2 \sigma(I))$ & $0.0510,0.0971$ & $0.1029,0.1944$ & $0.0394,0.0901$ \\
\hline$R 1, w R 2$ (all data) & $0.0973,0.1107$ & $0.2222,0.2438$ & $0.0586,0.0965$ \\
\hline largest diff peak and hole $\left(\mathrm{e} \AA^{-3}\right)$ & $0.720,-0.433$ & $0.718,-0.539$ & $0.490,-0.521$ \\
\hline
\end{tabular}




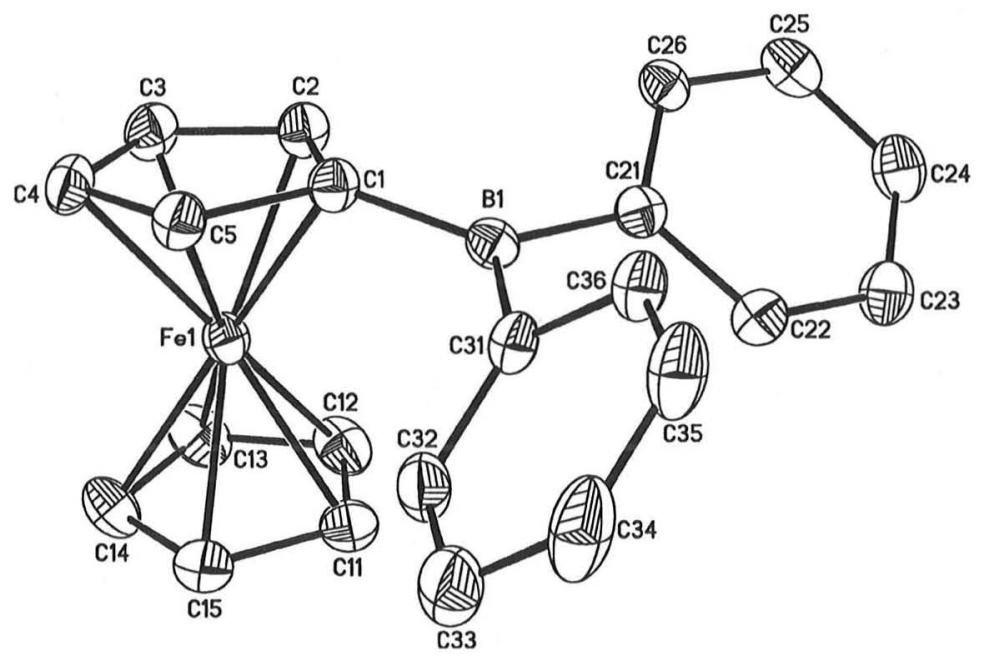

Fig. 2 Structure of 3 in the crystal. Displacement ellipsoids are drawn at the $30 \%$ probability level. $\mathrm{H}$ atoms omitted for clarity. Selected bond lengths $(\AA)$, bond angles $\left({ }^{\circ}\right)$, and the dip angle $\alpha^{*}\left({ }^{\circ}\right)$ : $\mathrm{B}(1)-\mathrm{C}(1)=1.542(5), \mathrm{B}(1)-\mathrm{C}(21)=1.579(5), \mathrm{B}(1)-\mathrm{C}(31)=1.581(5) ; \mathrm{C}(1)-\mathrm{B}(1)-\mathrm{C}(21)=122.4(3)$, $\mathrm{C}(1)-\mathrm{B}(1)-\mathrm{C}(31)=121.1(3), \mathrm{C}(21)-\mathrm{B}(1)-\mathrm{C}(31)=116.5(3) ; \alpha^{*}=13.0$.

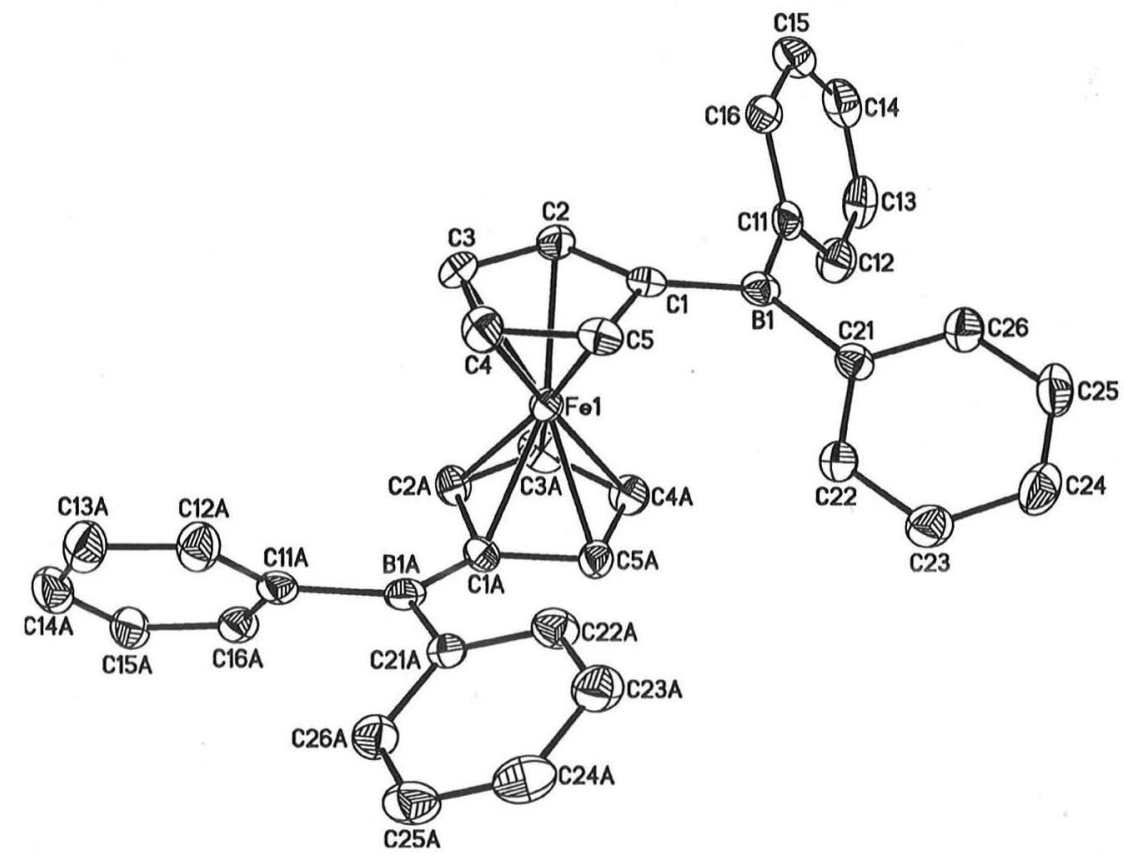

Fig. 3 Structure of 6 in the crystal. Displacement ellipsoids are drawn at the 50\% probability level. $\mathrm{H}$ atoms omitted for clarity. Selected bond lengths $(\AA)$, bond angles $\left({ }^{\circ}\right)$, and the dip angle $\alpha^{*}\left({ }^{\circ}\right)$ : $\mathrm{B}(1)-\mathrm{C}(1)=1.542(5), \mathrm{B}(1)-\mathrm{C}(11)=1.585(6), \mathrm{B}(1)-\mathrm{C}(21)=1.584(6) ; \mathrm{C}(1)-\mathrm{B}(1)-\mathrm{C}(11)=119.2(3)$, $\mathrm{C}(1)-\mathrm{B}(1)-\mathrm{C}(21)=123.1(3), \mathrm{C}(11)-\mathrm{B}(1)-\mathrm{C}(21)=117.6(3) ; \alpha^{*}=10.8$.

further supported by the observation of almost equal distances between the cyclopentadienyl rings of the three ferrocene fragments in $(\mathrm{Li}(12-\mathrm{c}-4)(\mathrm{THF}))_{2}[10](\mathrm{COG}(1)-\mathrm{COG}(1 \mathrm{~A})=3.330 \AA$, $\operatorname{COG}(11)-\operatorname{COG}(21)=3.325 \AA)$, with values characteristic of ferrocenes containing $\mathrm{Fe}^{\mathrm{II}}$ ions. ${ }^{19,31}$ In contrast, $\mathrm{Li}(12-\mathrm{c}-4)_{2}[10]$ exhibits similar centroid - centroid distances only for the terminal ferrocenyl substituents (COG(21)-COG(31) = 3.329 $\AA$ ), while the central moiety is significantly expanded $(\mathrm{COG}(11)-\mathrm{COG}(11 \mathrm{~A})=$ $3.420 \AA$ ). We take this as evidence that $\mathrm{Fe}(1)$ in $\mathrm{Li}(12-\mathrm{c}-4)_{2}[10]$ is an $\mathrm{Fe}^{\text {III }}$ centre. ${ }^{19,31}$ The $\mathrm{B}-\mathrm{Cp}$ and $\mathrm{B}-\mathrm{Ph}$ bond lengths are the same in $(\mathrm{Li}(12-\mathrm{c}-4)(\mathrm{THF}))_{2}[10]$ and in $\mathrm{Li}(12-\mathrm{c}-4)_{2}[10]$ (cf. Fig. 4 and 5). This is in agreement with a priori expectations, because differences in the $\pi$-donor strengths of both aromatic substituents are only relevant for three-coordinate boranes like 3 and 6 but not for compounds containing four-coordinate boron atoms. The central 1, $1^{\prime}$-ferrocenediyl fragments in ( $\mathrm{Li}(12-\mathrm{c}-$ 4)(THF) $)_{2}[10]$ and $\mathrm{Li}(12-\mathrm{c}-4)_{2}[10]$ adopt staggered conformations with boron substituents pointing in opposite directions. The major difference in the overall conformations of both oligomers lies in the position of the terminal ferrocenyl substituents 


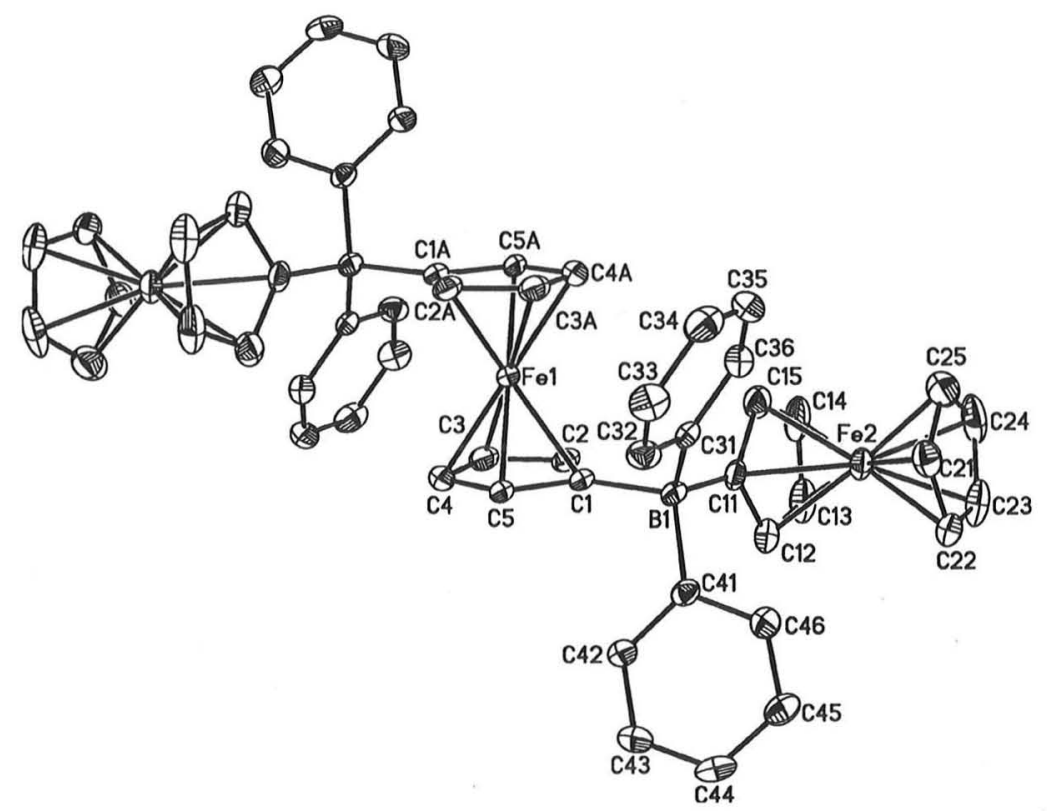

Fig. 4 Structure of $(\mathrm{Li}(12-\mathrm{c}-4)(\mathrm{THF}))_{2}[10]$ in the crystal. Displacement ellipsoids are drawn at the $50 \%$ probability level. $\mathrm{H}$ atoms and $\mathrm{Li}(12-\mathrm{c}-4)(\mathrm{THF})^{+}$ counterions omitted for clarity. Selected bond lengths $(\AA)$, atom $\cdots$ atom distances $(\AA)$, and bond angles $\left({ }^{\circ}\right)$ : $\mathrm{B}(1)-\mathrm{C}(1)=1.658(4), \mathrm{B}(1)-\mathrm{C}(11)=1.646(5)$, $\mathrm{B}(1)-\mathrm{C}(31)=1.647(5), \mathrm{B}(1)-\mathrm{C}(41)=1.663(4), \mathrm{COG}(1)-\mathrm{COG}(1 \mathrm{~A})=3.330, \mathrm{COG}(11)-\mathrm{COG}(21)=3.325, \mathrm{Fe}(1) \cdots \mathrm{Fe}(2)=6.112(1) ; \mathrm{C}(1)-\mathrm{B}(1)-\mathrm{C}(11)=$ $105.3(3), C(31)-B(1)-C(4 I)=106.9(3) . C O G(X)$ : centroid of the cyclopentadienyl ring containing the carbon atom $C(X)$. Symmetry transformations used to generate equivalent atoms: $\mathrm{A}:-x+1,-y,-z+1$.

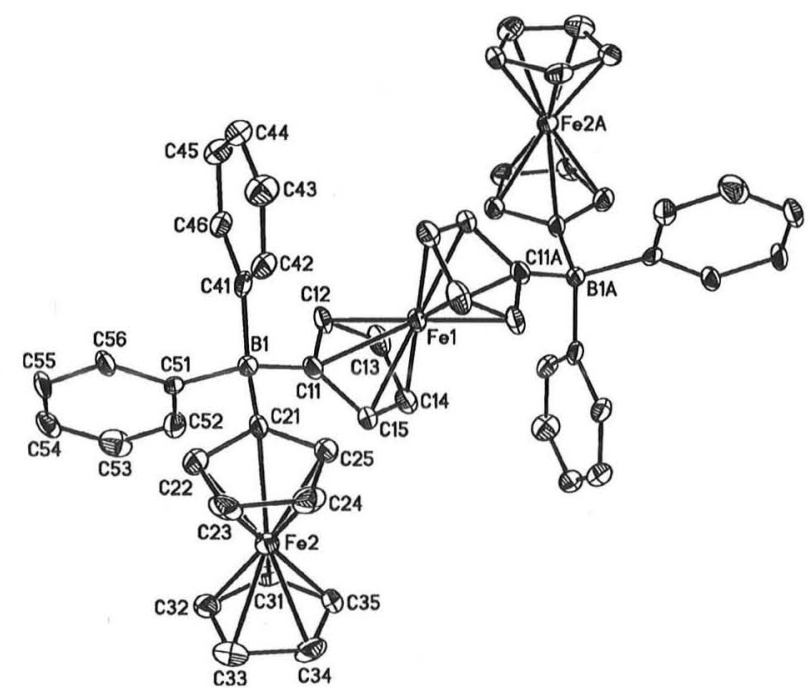

Fig. 5 Structure of $\operatorname{Li}(12-c-4)_{2}[10]$ in the crystal. Displacement ellipsoids are drawn at the $50 \%$ probability level. $\mathrm{H}$ atoms, the Li(12-crown- 4$)_{2}{ }^{+}$ counterion and the THF molecule omitted for clarity. Selected bond lengths $(\AA)$, atom $\cdots$ atom distances $(\AA)$, and bond angles $\left({ }^{\circ}\right)$ : $\mathrm{B}(1)-\mathrm{C}(11)=$ $1.646(12), \mathrm{B}(1)-\mathrm{C}(21)=1.644(12), \mathrm{B}(1)-\mathrm{C}(41)=1.649(13), \mathrm{B}(1)-\mathrm{C}(51)=$ $1.649(12), \quad \operatorname{COG}(11)-\operatorname{COG}(11 \mathrm{~A})=3.420, \quad \operatorname{COG}(21)-\operatorname{COG}(31)=$ $3.329, \quad \mathrm{Fe}(1) \cdots \mathrm{Fe}(2)=5.477(1) ; \mathrm{C}(11)-\mathrm{B}(1)-\mathrm{C}(21)=112.4(6)$, $\mathrm{C}(41)-\mathrm{B}(1)-\mathrm{C}(51)=111.3(6)$. $\operatorname{COG}(\mathrm{X})$ : centroid of the cyclopentadienyl ring containing the carbon atom $C(X)$. Symmetry transformations used to generate equivalent atoms: A: $-x+1,-y+1,-z$.

with respect to the central ferrocene moiety (dihedral angles: $(\mathrm{Li}(12-\mathrm{c}-4)(\mathrm{THF}))_{2}[10]: \mathrm{Cp}(\mathrm{C}(1)) / / \mathrm{Cp}(\mathrm{C}(11))=83.0^{\circ}$; $\mathrm{Li}(12-\mathrm{c}-$ 4) $)_{2}[10]$ : $\left.\mathrm{Cp}(\mathrm{C}(11)) / / \mathrm{Cp}(\mathrm{C}(21))=41.1^{\circ}\right)$.
The crystal lattice of the tetrakis(ferrocenyl)borate salt $\mathrm{Li}(\mathrm{THF})_{4}[11]$ contains tetrahedrally coordinated cations and anions; the molecular structure of the $\left[\mathrm{BFC}_{4}\right]^{-}$ion is shown in Fig. 6. We note a nearly threefold axis normal to the plane defined by $\mathrm{Fe}(1), \mathrm{Fe}(2)$, and $\mathrm{Fe}(3)$. As a result, the fourth ferrocenyl unit, i.e. that labeled $\mathrm{Fe}(4)$ in Fig. 6, is distinct from the others. Thus, the conformation of $\left[\mathrm{BFc}_{4}\right]^{-}$in $\mathrm{Li}(\mathrm{THF})_{4}[11]$ is strikingly similar to that of the neutral mixed-valent species $11 .{ }^{19}$ All B-C bond lengths of $\mathrm{Li}(\mathrm{THF})_{4}[11]$ fall in the interval between $\mathrm{B}(1)-\mathrm{C}(21)=$ $1.634(4) \AA$ and $\mathrm{B}(1)-\mathrm{C}(11)=1.653(4) \AA$; the smallest $\mathrm{C}-\mathrm{B}-\mathrm{C}$ angle is $\mathrm{C}(11)-\mathrm{B}(1)-\mathrm{C}(31)=103.2(2)^{\circ}$, the largest $\mathrm{C}(21)-\mathrm{B}(1)$ $\mathrm{C}(31)=113.0(2)^{\circ}$. Most importantly, all four centroid-to-centroid distances within the ferrocenyl substituents lie between $3.312 \AA$ and $3.318 \AA$ and are thus characteristic of $\mathrm{Fe}^{\mathrm{II}}$ states. This is in contrast to the molecular structure reported for the mixed-valent species 11, which contains three ferrocenyl groups with short centroid-to-centroid distances (3.291 $\AA$ to $3.320 \AA$; Fe $\mathrm{F}^{\text {Il }}$ states), and one substituent with a significantly elongated centroid-tocentroid distance (3.428 $\AA ; \mathrm{Fe}^{\mathrm{III}}$ state). ${ }^{19}$

\section{Electrochemical and spectroelectrochemical investigations}

The electrochemical parameters of the redox events exhibited by $\mathrm{Li}[\mathbf{9}],{ }^{23} \mathrm{Li}_{2}[\mathbf{1 0}], \mathrm{Li}[\mathbf{1 0}]$ and the related complexes $\mathrm{Li}\left[\mathrm{Fc}-\mathrm{BMe}_{2}-\mathrm{Fc}\right]^{13}$ and $\mathrm{Li}_{2}\left[\mathrm{Fc}-\mathrm{BMe}_{2}-\mathrm{fc}-\mathrm{BMe}_{2}-\mathrm{Fc}\right]^{13}$ are summarized in Table 3.

Each of the dinuclear complexes $\mathrm{Li}[9]$ and $\mathrm{Li}\left[\mathrm{Fc}-\mathrm{BMe}_{2}-\mathrm{Fc}\right]$ displays two oxidation processes of relative intensity $1: 1$, assignable as successive one-electron transitions at the two ferrocenyl moieties. In the case of the phenyl derivative Li[9], both electron transitions are reversible at $\mathrm{r}$. t. on the cyclic voltammetric timescale, whereas the methyl derivative $\mathrm{Li}\left[\mathrm{Fc}-\mathrm{BMe}_{2}-\mathrm{Fc}\right]$ has to be examined at $-78^{\circ} \mathrm{C}$ in order to obtain cyclic voltammograms showing features 
Table 3 Formal electrode potentials $E_{1 / 2}\left(v s\right.$. $\mathrm{FcH} / \mathrm{FcH}^{+}$) and peak-to-peak separations $\Delta E$ (at $0.1 \mathrm{~V} \mathrm{~s}^{-1}$ ) for the $\mathrm{Fe}^{\mathrm{Il}} / \mathrm{Fe}^{\mathrm{III}}$ redox processes exhibited by compounds $\mathrm{Li}[\mathbf{9}],{ }^{23} \mathrm{Li}_{2}[\mathbf{1 0}], \mathrm{Li}[\mathbf{1 0}], \mathrm{Li}\left[\mathrm{Fc}-\mathrm{BMe}_{2}-\mathrm{Fc}\right],{ }^{13}$ and $\mathrm{Li}_{2}\left[\mathrm{Fc}-\mathrm{BMe}_{2}-\mathrm{fc}-\mathrm{BMe}_{2}-\mathrm{Fc}\right]^{13}$

\begin{tabular}{llllll}
\hline & $E_{1 / 2}[\mathrm{~V}]$ & $\Delta E[\mathrm{mV}]$ & $\Delta E_{1 / 2}[\mathrm{mV}]$ & solvent & $\Delta E(\mathrm{FcH})[\mathrm{mV}]$ \\
\hline $\mathrm{Li}[9]$ & $-0.38 /-0.64$ & $99 / 97$ & 260 & $\mathrm{CH}_{2} \mathrm{Cl}_{2}$ & 103 \\
$\mathrm{Li}[10]$ & $-0.45 /-1.18$ & $125 / 82$ & 730 & $\mathrm{CH}_{2} \mathrm{Cl}_{2}$ & 122 \\
$\mathrm{Li}[10]$ & $-0.45 /-1.18$ & $19 / 85$ & 730 & $\mathrm{CH}_{2} \mathrm{Cl}_{2}$ & 108 \\
$\mathrm{Li}\left[\mathrm{F}-\mathrm{BMe}_{2}-\mathrm{Fc}^{a}\right.$ & $-0.43 /-0.64$ & $90 / 100$ & 210 & $\mathrm{CH}_{2} \mathrm{Cl}_{2}$ & 100 \\
$\mathrm{Li}_{2}\left[\mathrm{Fc}-\mathrm{BMe}_{2}-\mathrm{fc}-\mathrm{BMe}_{2}-\mathrm{Fc}\right]^{a}$ & $-0.51 /-1.21$ & $330 / 210$ & 700 & $\mathrm{CH}_{2} \mathrm{Cl}_{2}$ & 250
\end{tabular}

${ }^{a}$ recorded at a scan rate of $0.2 \mathrm{Vs}^{-1}$ and at a temperature of $-78^{\circ} \mathrm{C}$.

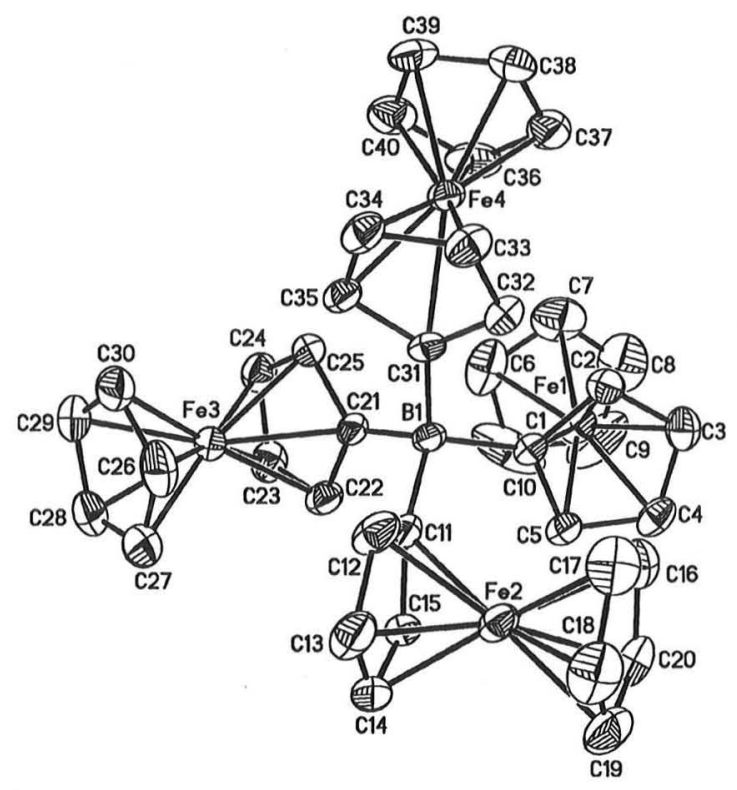

Fig. 6 Structure of $\mathrm{Li}(\mathrm{THF})_{4}[11]$ in the crystal. Displacement ellipsoids are drawn at the $50 \%$ probability level. $\mathrm{H}$ atoms and the $\mathrm{Li}(\mathrm{THF})_{4}{ }^{+}$counterion omitted for clarity. Selected bond lengths $(\AA)$, atom $\cdots$ atom distances $(\AA)$, and bond angles $\left({ }^{\circ}\right)$ : $\mathrm{B}(1)-\mathrm{C}(1)=1.648(4), \mathrm{B}(1)-\mathrm{C}(11)=1.653(4), \mathrm{B}(1)-\mathrm{C}(21)=1.634(4)$, $\mathrm{B}(1)-\mathrm{C}(31)=1.644(4), \mathrm{COG}(1)-\mathrm{COG}(6)=3.312, \mathrm{COG}(11)-\mathrm{COG}(16)=$ $3.318, \operatorname{COG}(21)-\operatorname{COG}(26)=3.314, \operatorname{COG}(31)-\operatorname{COG}(36)=3.314$, av. $\mathrm{Fe} \cdots \mathrm{Fe}=5.675(1) ; \mathrm{C}(1)-\mathrm{B}(1)-\mathrm{C}(11)=109.6(2), \mathrm{C}(1)-\mathrm{B}(1)-\mathrm{C}(21)=$ $109.6(2), \mathrm{C}(1)-\mathrm{B}(1)-\mathrm{C}(31)=111.8(2), \mathrm{C}(11)-\mathrm{B}(1)-\mathrm{C}(21)=109.4(2)$, $\mathrm{C}(11)-\mathrm{B}(1)-\mathrm{C}(31)=103.2(2), \mathrm{C}(21)-\mathrm{B}(1)-\mathrm{C}(31)=113.0(2) \cdot \operatorname{COG}(\mathrm{X})$ : centroid of the cyclopentadienyl ring containing the carbon atom $\mathrm{C}(\mathrm{X})$.

of chemical reversibility. Moreover, when also determined at a temperature of $-78{ }^{\circ} \mathrm{C}$, both $E_{1 / 2}$ values of $\mathrm{Li}[9](-0.35 \mathrm{~V} /$ $-0.57 \mathrm{~V}$ ) are anodically shifted by about $0.08 \mathrm{~V}$ with respect to the redox potentials of $\mathrm{Li}\left[\mathrm{Fc}-\mathrm{BMe}_{2}-\mathrm{Fc}\right](-0.43 \mathrm{~V} /-0.64 \mathrm{~V})$, which can easily be explained by the greater electronegativity of the phenyl rings as compared to methyl substituents.

The cyclic voltammograms of the trinuclear complexes $\mathrm{Li}_{2}[10]$ and $\mathrm{Li}[10]$ are congruent to each other and reveal two redox events with an intensity ratio of $1: 2$ (Fig. 7; note that the different oxidation states of $\mathrm{Li}_{2}[\mathbf{1 0}]$ and $\mathrm{Li}[\mathbf{1 0}]$ have been confirmed by linear sweep voltammetry).

Both these processes are chemically reversible as evidenced by the following criteria: the current ratios $i_{\mathrm{pc}} / i_{\mathrm{pa}}$ are constantly equal to 1 , the current functions $i_{\mathrm{pa}} / v^{\frac{1}{2}}$ remain constant, and the peakto-peak separations $(\Delta E)$ do not depart appreciably from the value

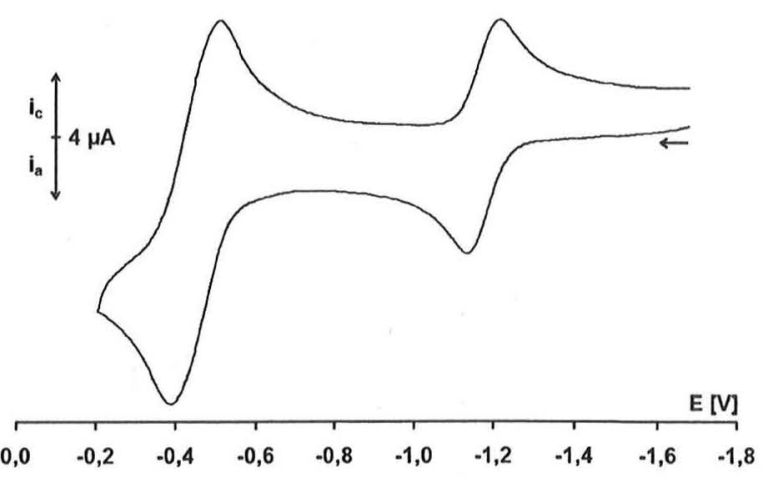

Fig. 7 Cyclic voltammogram of $\mathrm{Li}_{2}[10]\left(\mathrm{CH}_{2} \mathrm{Cl}_{2},\left[\mathrm{NBu}_{4}\right]\left[\mathrm{PF}_{6}\right]\right.$ as supporting electrolyte $(0.1 \mathrm{M})$, scan rate $0.1 \mathrm{~V} \mathrm{~s}^{-1} ; v s$. $\left.\mathrm{FcH} / \mathrm{FcH}^{+}\right)$.

found for the internal ferrocene standard $(\Delta E(\mathrm{FcH})$, Table 3; theoretically expected value for a chemically and electrochemically reversible one-electron step: $59 \mathrm{mV}$ ). The more anodic twoelectron transfer at $E_{1 / 2}=-0.45 \mathrm{~V}$ can be attributed to the terminal ferrocenyl moieties, while the less anodic one-electron redox event at $E_{1 / 2}=-1.18 \mathrm{~V}$ takes place at the interior iron centre. These data agree with the results obtained from electrochemical investigations of $\mathrm{Li}_{2}\left[\mathrm{Fc}-\mathrm{BMe}_{2}-\mathrm{fc}-\mathrm{BMe}_{2}-\mathrm{Fc}\right]$. However, as in the case of $\mathrm{Li}[9]$ and $\mathrm{Li}\left[\mathrm{Fc}-\mathrm{BMe}_{2}-\mathrm{Fc}\right]$, the $E_{1 / 2}$ values of $\mathrm{Li}_{2}[\mathbf{1 0}] / \mathrm{Li}[\mathbf{1 0}]$ are slightly shifted to the anodic regime compared to the redox potentials of $\mathrm{Li}_{2}\left[\mathrm{Fc}-\mathrm{BMe}_{2}-\mathrm{fc}-\mathrm{BMe}_{2}-\mathrm{Fc}\right]$ (Table 3 ).

Oxidation of the $1,1^{\prime}$-ferrocenylene unit in $\mathrm{Li}_{2}[10]$ takes place at a much more cathodic redox potential than oxidation of the terminal ferrocenyl groups $\left(\Delta E_{1 / 2}=730 \mathrm{mV}\right)$ which is clearly due to the fact that the former has two negatively charged substituents, while each of the latter bears only one such group. The Fc moieties of $\mathrm{Li}[9]$ are, however, chemically equivalent. The comparatively large differences of more than $200 \mathrm{mV}$ between the redox potentials of the two $\mathrm{Fe}^{\mathrm{Il}} / \mathrm{Fe}^{\mathrm{III}}$ transitions in $\mathrm{Li}[9]$ as well as $\mathrm{Li}\left[\mathrm{Fc}-\mathrm{BMe}_{2}\right.$ $\mathrm{Fc}$ ] indicate that the two $\mathrm{Fc}$ subunits are mutually interacting. The question thus arises whether this interaction is entirely electrostatic in nature or whether there is a certain degree of charge delocalization via four-coordinate boron linkers or even throughspace. The latter assumption is supported by the finding of a very broad band with a maximum near $2200 \mathrm{~nm}$ in the electronic spectrum of the $\mathrm{Fe}^{\mathrm{Il}}{ }_{3} \mathrm{Fe}^{\mathrm{III}}$ species $11 .{ }^{19}$ It has been suggested that this absorption is due to intervalence charge-transfer processes which may proceed by a through-space mechanism.

In view of this background, we decided to carry out spectroelectrochemical measurements on the dinuclear compound Li[9] and to look for intervalence charge-transfer (IVCT) bands. To this end, we have performed a coulometrically controlled 
one-electron oxidation at a working potential of $-0.5 \mathrm{~V}\left(\mathrm{CH}_{2} \mathrm{Cl}_{2}\right.$, $\left.\left[\mathrm{NBu}_{4}\right]\left[\mathrm{PF}_{6}\right](0.1 \mathrm{M})\right)$ and simultaneously recorded the changes in the UV/vis/NIR spectrum of the solution. Prior to oxidation, we observe the lowest-energy band at $\lambda_{\max }=470 \mathrm{~nm}$ which compares reasonably well to the absorption band at $\lambda_{\max }=442 \mathrm{~nm}$ exhibited by parent ferrocene under the same conditions. After exhaustive one-electron oxidation, the resulting $\mathrm{Fe}^{\mathrm{II}} \mathrm{Fe}^{\mathrm{III}}$ species 9 still showed a band at $\lambda_{\max }=471 \mathrm{~nm}$ and, in addition, an absorption at $\lambda_{\max }=$ $698 \mathrm{~nm}\left(c f .\left[\left(\mathrm{C}_{5} \mathrm{H}_{5}\right)_{2} \mathrm{Fe}\right] \mathrm{PF}_{6}: \lambda_{\max }=635 \mathrm{~nm}\right)$. After exhaustive twoelectron oxidation at an applied voltage of $0.1 \mathrm{~V}$, only a very broad band at $\lambda_{\max }=619 \mathrm{~nm}$ remained in this region of the spectrum. Most importantly, at no stage did we observe any feature at longer wavelengths than $900 \mathrm{~nm}$ that might be interpretable as $\mathrm{Fe}^{\mathrm{II}} / \mathrm{Fe}^{\mathrm{III}}$ IVCT band. An IVCT absorption is also absent in the electronic spectrum of the $\mathrm{Fe}_{2}{ }_{2} \mathrm{Fe}^{\mathrm{III}}$ mixed-valent complex Li[10]. In order to test our spectroelectrochemical setup we also re-investigated the tetraferrocenylborate $\mathrm{Li}[11]$ and have fully reproduced the published spectral data ${ }^{19}$ including the IVCT band. We have moreover observed that upon further oxidation of mixed-valent $11\left(\mathrm{Fe}_{3}{ }_{3} \mathrm{Fe}^{\mathrm{III}}\right)$ to $[11]^{+}\left(\mathrm{Fe}_{2}{ }_{2} \mathrm{Fe}^{\mathrm{III}}{ }_{2}\right)$ and to $[11]^{2+}\left(\mathrm{Fe}^{\mathrm{II}} \mathrm{Fe}^{\mathrm{III}}{ }_{3}\right)$ the broad featureless NIR band first intensifies and then decreases in intensity ( $c f$. Fig. $2 \mathrm{~S}$ of the ESI $\dagger$ ). Upon potential reversal and subsequent reduction these changes are reversible.

\section{${ }^{57} \mathrm{Fe}$ Mößbauer spectroscopy}

Since there are no analytically pure and solid samples of the mixedvalent $\mathrm{Fe}^{\mathrm{II}} \mathrm{Fe}^{\mathrm{III}}$ species 9 available, we had to restrict our Mößbauer spectroscopic studies to the trinuclear $\mathrm{Fe}_{2}{ }_{2} \mathrm{Fe}^{\mathrm{III}}$ compound $\mathrm{Li}[\mathbf{1 0}]$.

Mößbauer data were acquired on single crystals of $\mathrm{Li}(12-\mathrm{c}-$ 4) $)_{2}[10]$ in the temperature range $97.5 \mathrm{~K} \leq T \leq 304 \mathrm{~K}$. We first consider the spectrum taken at $97.5 \mathrm{~K}$ which is shown in the lower trace of Fig. 8. The spectrum consists of two distinct iron sites, $\mathrm{Fe}$ and $\mathrm{Fe}^{\prime}$, and the relative area under the resonance curve is $\mathrm{Fe}$ : $\mathrm{Fe}^{\prime} \approx 2: 1$. This already suggests $\mathrm{Fe}$ to correspond to the $\mathrm{Fe}^{\prime \prime}$ sites and $\mathrm{Fe}^{\prime}$ to the unique $\mathrm{Fe}^{\mathrm{III}}$ site of $\mathrm{Li}(12-\mathrm{c}-4)_{2}[10]$. At $90 \mathrm{~K}$, the isomer shifts (IS) are $0.529 \pm 0.002 \mathrm{~mm} \mathrm{~s}^{-1}$ (Fe) and $0.50 \pm$ $0.04 \mathrm{~mm} \mathrm{~s}^{-1}\left(\mathrm{Fe}^{\prime}\right)$ and the corresponding quadrupole splittings (QS) are $2.379 \pm 0.002 \mathrm{~mm} \mathrm{~s}^{-1}(\mathrm{Fe})$ and $-0.24 \pm 0.02 \mathrm{~mm} \mathrm{~s}^{-1}$ ( $\mathrm{Fe}^{\prime}$; Note: It is not always possible to record Mößbauer spectra at exactly $90 \mathrm{~K}$. To effect intersample comparison, the hyperfine parameter data have been linearly extrapolated to $90 \mathrm{~K}$ and those values are reported herein). The $\mathrm{QS}$ of the $\mathrm{Fe}^{\prime}$ site is negative, as has previously been observed for ferricinium centres in related compounds. ${ }^{32}$

The qualitative picture remains the same irrespective of the temperature applied during measurements. This leads to the conclusion that there is no electron delocalization over the three iron centres in the entire interval $97.5 \mathrm{~K} \leq T \leq 304 \mathrm{~K}$. However, it should be noted that at higher temperatures the $\mathrm{Fe}^{\mathrm{III}}$ resonance sharpens and becomes a well-defined doublet, as shown in the upper trace of Fig. 8. This observation is consistent with a spinlattice relaxation process (vide infra).

The temperature dependence of the IS for the $\mathrm{Fe}^{11}$ site $\mathrm{Fe}$ can be fitted by a linear regression with a correlation coefficient of 0.992 for 11 data points $\left(\right.$ slope $\left.=-(4.12 \pm 0.15) \cdot 10^{-4} \mathrm{~mm} \mathrm{~s}^{-1} \mathrm{~K}^{-1}\right)$. From this temperature dependence, the effective vibrating mass of the metal centre is calculated to be $M_{\text {eff }}=101 \pm 3$ Daltons. Likewise, the $\ln$ of the temperature dependence of the recoil-free fraction

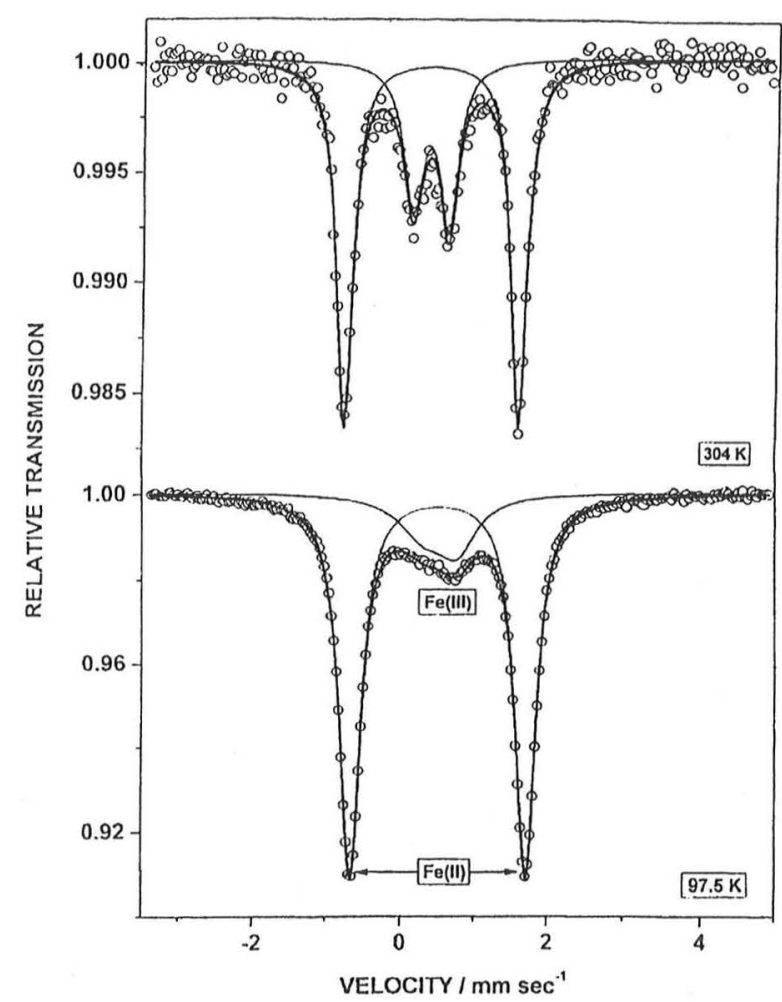

Fig. $8{ }^{57} \mathrm{Fe} \mathrm{Mößbauer} \mathrm{spectrum} \mathrm{of} \mathrm{Li}(12-\mathrm{c}-4)_{2}[10]$ at $97.5 \mathrm{~K}$ (lower trace). The velocity scale is with respect to the centroid of a r. t. $\alpha-\mathrm{Fe}$ spectrum. The corresponding spectrum at $304 \mathrm{~K}$ is shown in the upper trace and confirms the absence of electron delocalization between the iron sites, as discussed in the text.

averaged over both types of iron sites (as determined from the areas under the resonance curves) is linear over the whole temperature range (slope $=-(9.89 \pm 0.44) \cdot 10^{-3} \mathrm{~K}^{-1}$; correlation coefficient $=$ 0.99 for 7 data points). From these data it is possible to calculate the parameter $\left.F_{\mathrm{M} 173}=k^{2}<x_{\mathrm{ave}}^{2}\right\rangle(k$ : wave vector of the Mößbauer $\gamma$-ray; $x_{\text {ave }}{ }^{2}$ : average root-mean-square amplitude of vibration of the iron atom), which can be compared to the parameter $F_{\mathrm{X} 173}$ as it has been extracted from the $U_{\mathrm{ij}}$ value determined by Xray crystallography on $\mathrm{Li}(12-\mathrm{c}-4)_{2}[\mathbf{1 0}]$ at $173 \mathrm{~K}$. This comparison reveals the two parameters, $F_{\mathrm{M} 173}=1.70$ and $F_{\mathrm{X} 173}=1.73$, to be in excellent agreement with each other. The root-mean-square amplitudes of vibration of the Fe atoms in $\mathrm{Li}(12-\mathrm{c}-4)_{2}[\mathbf{1 0}]$ derived from the Mößbauer data are $0.193 \AA, 0.215 \AA$, and $0.236 \AA$ at $200 \mathrm{~K}, 250 \mathrm{~K}$, and $300 \mathrm{~K}$, respectively.

As mentioned above, the paramagnetic $\mathrm{Fe}^{\mathrm{III}}$ centre $\mathrm{Fe}^{\prime}$ relaxes by spin-lattice relaxation and obeys a fifth order power law, indicative of a Raman process, as has previously been reported for other $S=$ $5 / 2$ spin systems. ${ }^{33}$ The relaxation is slow (on the Mößbauer time scale) below $150 \mathrm{~K}$, but becomes rapid at higher temperatures ( $c f$. Fig. 9 for a plot of the temperature dependence of the relaxation rate).

\section{Conclusion}

We have shown that the molecular framework of $\mathrm{BPh}_{2}$-bridged oligoferrocenes $\mathrm{Li}\left[\mathrm{Fc}-\mathrm{BPh}_{2}-\mathrm{Fc}\right](\mathrm{Li}[9])$ and $\mathrm{Li}_{2}\left[\mathrm{Fc}-\mathrm{BPh}_{2}-\mathrm{fc}-\mathrm{BPh}_{2}\right.$ $\mathrm{Fc}]\left(\mathrm{Li}_{2}[10]\right)$ remains intact when the iron atoms are oxidized $(\mathrm{Fc}$ : 


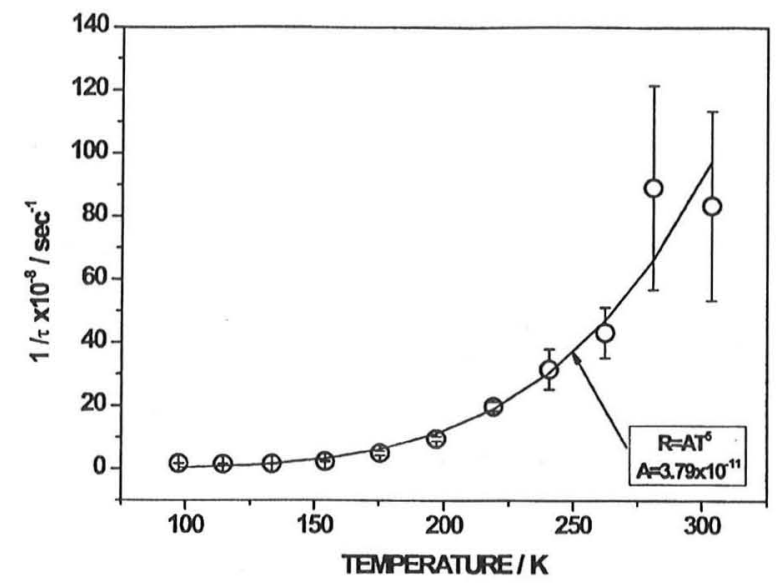

Fig. 9 Temperature dependence of the spin-lattice relaxation process for the $\mathrm{Fe}^{\mathrm{III}}$ site in $\mathrm{Li}(12-\mathrm{c}-4)_{2}[\mathbf{1 0}]$. The solid line represents a fifth order temperature dependence indicative of a Raman-type relaxation process.

$\left.\left(\mathrm{C}_{5} \mathrm{H}_{5}\right) \mathrm{Fe}\left(\mathrm{C}_{5} \mathrm{H}_{4}\right)\right)$. A corresponding $\mathrm{Fe}_{2}{ }_{2} \mathrm{Fe}^{\mathrm{III}}$ mixed-valent species $\mathrm{Li}\left[\mathrm{Fc}-\mathrm{BPh}_{2}-\mathrm{fc}-\mathrm{BPh}_{2}-\mathrm{Fc}\right](\mathrm{Li}[10])$ has been structurally characterized by X-ray crystallography. Both the crystallographical data and ${ }^{57} \mathrm{Fe}$ Mößbauer spectroscopy on $\mathrm{Li}[\mathbf{1 0}]$ point towards a largely localized electronic structure with the central iron atom adopting an oxidation state of +III. Moreover, spectroelectrochemical measurements on $\mathrm{Li}[9]$ and $\mathrm{Li}_{2}[10]$ in the UV/vis/NIR region do not reveal absorption bands assignable to intervalence chargetransfer processes after partial oxidation of the compounds. This is in striking contrast to published data (which have been confirmed by our own measurements) on the $\mathrm{Fe}^{\mathrm{II}}{ }_{3} \mathrm{Fe}^{\mathrm{II}}$ mixedvalent complex $\mathrm{Fc}_{4} \mathrm{~B}$ (11) for which electron delocalization has been observed. To account for this different behaviour, we offer two explanations: (i) In the dinuclear molecule $\left[\mathrm{Fc}^{\mathrm{II}} \mathrm{Fc}^{\mathrm{II}} \mathrm{BPh}_{2}\right]$ (9), $\mathrm{Fe}^{\mathrm{Il}} \rightarrow \mathrm{Fe}^{\mathrm{III}}$ charge transfer is three times less likely than in the tetranuclear compound $\left[\mathrm{Fc}^{\mathrm{III}}\left(\mathrm{Fc}^{\mathrm{II}}\right)_{3} \mathrm{~B}\right]$ (11). As a result, the absorbance of a hypothetical IVCT band of 9 should be considerably smaller than the corresponding value of the IVCT band of 11 , which is already rather low $(\varepsilon=300)$. (ii) If electron transfer in $\mathbf{1 1}$ proceeds via a through-space mechanism (as has been suggested by Cowan et al. ${ }^{19}$ ) the average $\mathrm{Fe} \cdots \mathrm{Fe}$ distance becomes a decisive factor. Since the ferrocenyl substituents in $\mathbf{1 1}$ are much more densely packed than in 9, a through-space chargetransfer operative in $\mathbf{1 1}$ may well no longer be possible in $\mathbf{9}$ ( $c f$. the solid state structure of $\mathrm{Li}\left(\mathrm{OBu}_{2}\right)[9]^{23}$ shows that conformations of this molecule are possible in which the $\mathrm{Fe} \cdots \mathrm{Fe}$ distance is as long as 6.679(1) $\AA$; in contrast, the average $\mathrm{Fe}$... Fe distance in the less flexible molecule $\mathrm{Li}(\mathrm{THF})_{4}[11]$ is only $5.675(1) \AA$ ).

We therefore conclude that electronic interaction between the individual iron sites in $\mathrm{Li}[\mathbf{9}], \mathbf{9}, \mathrm{Li}_{2}[\mathbf{1 0}]$, and $\mathrm{Li}[\mathbf{1 0}]$ does probably not occur by charge delocalization via the $\mathrm{BPh}_{2}$-bridge, but is either a through-space process or of an electrostatic nature. In this context, it is interesting to compare the results of Curtis et al. on the degree of electronic communication within mixed-valent poly(ferrocenylenearylene)s. ${ }^{34}$ These authors find very similar behaviour to our oligomers (e.g. significant ferrocene-ferrocene interaction as measured by cyclic voltammetry, but little electron transfer as measured by NIR and Mößbauer spectroscopy), even though the polymer chains in poly(ferrocenylenearylene)s are conjugated, whereas in $\mathbf{9}$ and $\mathbf{1 0}$ there is no $\pi$-conjugation between the redox-active moieties.

\section{Experimental}

\section{General considerations}

All reactions were carried out under a nitrogen atmosphere using Schlenk tube techniques. Solvents were freshly distilled under argon from $\mathrm{Na}$ /benzophenone (diethyl ether, THF, $d_{8}$-THF), $\mathrm{Na} / \mathrm{Pb}$ alloy (pentane, hexane) or $\mathrm{CaH}_{2}\left(\mathrm{CH}_{2} \mathrm{Cl}_{2}, \mathrm{CDCl}_{3}\right)$ prior to use. NMR spectrometers: Bruker AM 250, AV 300 and AMX 400. Chemical shifts are referenced to residual solvent peaks (' $\mathrm{H}$, $\left.{ }^{13} \mathrm{C}\left\{{ }^{1} \mathrm{H}\right\}\right)$ or external $\mathrm{BF}_{3} \cdot \mathrm{Et}_{2} \mathrm{O}\left({ }^{11} \mathrm{~B}\left\{{ }^{\prime} \mathrm{H}\right\}\right)$. Abbreviations: $\mathrm{s}=$ singlet, $\mathrm{d}=$ doublet, $\mathrm{tr}=$ triplet, mult $=$ multiplet, $\mathrm{br}=$ broad, $o=$ ortho, $m=$ meta, $p=$ para, n.o. $=$ not observed, n.r. $=$ not resolved. All NMR spectra were run at r. t. Electrochemical measurements: Potentiostat EG\&G Princeton Applied Research 263 A. Compounds $\mathrm{FcHgCl}(1),{ }^{21} \mathrm{BrBPh}_{2}(2),{ }^{22}, \mathrm{FcLi}^{35}$ and $1,1^{\prime}-\mathrm{fcLi}_{2} \times 2 / 3$ TMEDA $(4)^{24,25}$ were synthesized according to literature procedures. The synthesis of $\mathrm{MeOBPh}_{2}(5)$ is described in the ESI.†

Synthesis of 3. A solution of $\mathrm{BrBPh}_{2} 2(0.53 \mathrm{~g}, 2.16 \mathrm{mmol})$ in hexane $(12 \mathrm{~mL})$ was added dropwise with stirring at $-78^{\circ} \mathrm{C}$ to a suspension of $\mathrm{FcHgCl} 1(0.91 \mathrm{~g}, 2.16 \mathrm{mmol})$ in hexane $(35 \mathrm{~mL})$. The reaction mixture was slowly warmed to $\mathrm{r}$. $\mathrm{t}$. and stirred overnight, whereupon a grey solid precipitated. After filtration, the filtrate was slowly evaporated in vacuo to a volume of $5 \mathrm{~mL}$ whereupon single crystals of 3 formed. Yield: $0.60 \mathrm{~g}(80 \%)$. ${ }^{1 "} \mathrm{~B}\left\{{ }^{\prime} \mathrm{H}\right\}$ NMR $\left(128.4 \mathrm{MHz}, \mathrm{CDCl}_{3}\right): \delta 63.3\left(h_{1 / 2}=600 \mathrm{~Hz}\right){ }^{1} \mathrm{H}$ NMR (400.1 MHz, $\left.\mathrm{CDCl}_{3}\right): \delta 4.18\left(\mathrm{~s}, 5 \mathrm{H}, \mathrm{C}_{5} \mathrm{H}_{5}\right), 4.54,4.82(2 \times$ n.r., $\left.2 \times 2 \mathrm{H}, \mathrm{C}_{5} \mathrm{H}_{4}\right), 7.40-7.46$ (mult, $6 \mathrm{H}, m-\mathrm{Ph}, p-\mathrm{Ph}$ ), 7.75 (d, $4 \mathrm{H}$, $\left.{ }^{3} J_{\mathrm{HH}}=7.6 \mathrm{~Hz}, o-\mathrm{Ph}\right) .{ }^{13} \mathrm{C}\left\{{ }^{1} \mathrm{H}\right\} \mathrm{NMR}\left(100.6 \mathrm{MHz}, \mathrm{CDCl}_{3}\right): \delta 69.4$ $\left(\mathrm{C}_{5} \mathrm{H}_{5}\right), 75.8,78.4\left(\mathrm{C}_{5} \mathrm{H}_{4}\right), 127.2(m-\mathrm{Ph}), 129.4(p-\mathrm{Ph}), 135.4(o$ $\mathrm{Ph}$ ), n.o. (BC). Elemental analysis: Calcd. for $\mathrm{C}_{22} \mathrm{H}_{19} \mathrm{BFe}$ (350.03): C, 75.49; H, 5.47. Found: C, 75.23; H, 5.50\%

Synthesis of 6 and 7. A solution of $\mathrm{MeOBPh}_{2} 5(0.36 \mathrm{~g}$, $1.86 \mathrm{mmol})$ in hexane $(10 \mathrm{~mL})$ was added dropwise with stirring at $-78^{\circ} \mathrm{C}$ to a suspension of $1,1^{\prime}-\mathrm{fcLi}_{2} \times 2 / 3$ TMEDA $4(0.26 \mathrm{~g}$, $0.93 \mathrm{mmol})$ in hexane $(15 \mathrm{~mL})$. The reaction mixture was slowly warmed to $r$. $t$. and stirred overnight. The resulting orange suspension was filtered and the filtrate was evaporated to a volume of $5 \mathrm{~mL}$. Red needles of 6 and colourless plates of 7 crystallized after the solution had been stored for several months at $-35^{\circ} \mathrm{C}$. The crystals were separated by manual selection in a glovebox. NMR data of 6: " $\mathrm{B}\left\{{ }^{\prime} \mathrm{H}\right\}$ NMR $\left(128.4 \mathrm{MHz}, \mathrm{CDCl}_{3}\right): \delta$ n.o. ${ }^{\prime} \mathrm{H}$ NMR (400.1 MHz, $\left.\mathrm{CDCl}_{3}\right): \delta 4.54,4.75\left(2 \times\right.$ n.r., $\left.2 \times 4 \mathrm{H}, \mathrm{C}_{5} \mathrm{H}_{4}\right)$, 7.39 (mult, $8 \mathrm{H}, m$ - $\mathrm{Ph}$ ), 7.47 (mult, $4 \mathrm{H}, p$ - $\mathrm{Ph}$ ), 7.68 (d, $8 \mathrm{H},{ }^{3} J_{\mathrm{HH}}=$ $7.2 \mathrm{~Hz}, o-\mathrm{Ph}) .{ }^{13} \mathrm{C}\left\{{ }^{\prime} \mathrm{H}\right\}$ NMR $\left(100.6 \mathrm{MHz}, \mathrm{CDCl}_{3}\right): \delta 76.6,79.4$ $\left(\mathrm{C}_{5} \mathrm{H}_{4}\right), 127.3(m-\mathrm{Ph}), 129.9(p-\mathrm{Ph}), 135.5(o-\mathrm{Ph})$, n.o. $(\mathrm{BC})$.

NMR data of 7: "'B $\left\{{ }^{\prime} \mathrm{H}\right\}$ NMR (128.4 MHz, $\left.d_{8}-\mathrm{THF}\right): \delta 2.5$ $\left(h_{1 / 2}=150 \mathrm{~Hz}\right)$. 'H NMR (400.1 MHz, $d_{8}$-THF): $\delta 2.15(\mathrm{~s}, 12 \mathrm{H}$, $\mathrm{NMe}), 2.31\left(\mathrm{~s}, 4 \mathrm{H}, \mathrm{NCH}_{2}\right), 3.11(\mathrm{~s}, 3 \mathrm{H}, \mathrm{OMe}), 6.86\left(\mathrm{tr}, 3 \mathrm{H},{ }^{3} J_{\mathrm{HH}}=\right.$ $7.6 \mathrm{~Hz}, p$ - Ph), 7.00 (mult, $6 \mathrm{H}, m-\mathrm{Ph}), 7.41$ (d, $6 \mathrm{H},{ }^{3} J_{\mathrm{HH}}=7.2 \mathrm{~Hz}$, $o$ - $\mathrm{Ph}) .{ }^{13} \mathrm{C}\left\{{ }^{\prime} \mathrm{H}\right\}$ NMR (100.6 MHz, $d_{8}$-THF): $\delta 46.4$ (NMe), 59.1 $\left(\mathrm{NCH}_{2}\right), 52.2(\mathrm{OMe}), 124.0(p-\mathrm{Ph}), 126.9(m-\mathrm{Ph}), 135.3(o-\mathrm{Ph})$, n.o. $(\mathrm{BC})$. 
Synthesis of $\mathrm{Li}_{2}[10]$ and $\mathrm{Li}[10]$. A solution of $\mathrm{FcBPh}_{2} 3$ $(0.15 \mathrm{~g}, 0.43 \mathrm{mmol})$ in THF $(8 \mathrm{~mL})$ was added dropwise with stirring at $-78{ }^{\circ} \mathrm{C}$ to a solution of $1,1^{\prime}-\mathrm{fcLi}_{2} \times 2 / 3$ TMEDA 4 $(0.06 \mathrm{~g}, 0.22 \mathrm{mmol})$ in THF $(12 \mathrm{~mL})$. The reaction mixture was slowly warmed to $r$. t. and stirred overnight. The volume of the solution was first reduced to $4 \mathrm{~mL}$ in vacuo and then 12-crown$4(0.27 \mathrm{~mL})$ and hexane $(10 \mathrm{~mL})$ were added. The resulting red precipitate was extracted with hexane $(3 \times 10 \mathrm{~mL})$. Single crystals of $(\mathrm{Li}(12-\mathrm{c}-4)(\mathrm{THF}))_{2}[10]$ were grown by gas-phase diffusion of hexane into a THF solution of the crude product under strict exclusion of air. Single crystals of $\operatorname{Li}(12-\mathrm{c}-4)_{2}[10]$ were grown under similar conditions but without strict exclusion of air. Yield of (Li(12-c-4)(THF) $)_{2}$ [10]: $0.10 \mathrm{~g}(33 \%)$. Yield of Li(12-c-4) $)_{2}[10]$ : $0.030 \mathrm{~g}(10 \%)$. NMR data of $(\mathrm{Li}(12-\mathrm{c}-4)(\mathrm{THF}))_{2}[10]$ : ${ }^{11} \mathrm{~B}\left\{{ }^{1} \mathrm{H}\right\}$ NMR (128.4 MHz, $d_{8}$-THF): $\delta-11.7\left(h_{1 / 2}=70 \mathrm{~Hz}\right)$. 'H NMR (400.1 MHz, $d_{8}$-THF): $\delta 3.59$ (s, 32H, 12-c-4), 3.68 (very br, $\left.\mathrm{C}_{5} \mathrm{H}_{4} / \mathrm{C}_{5} \mathrm{H}_{5}\right), 6.63(\mathrm{br}, 4 \mathrm{H}, p-\mathrm{Ph}), 6.79,7.35(2 \times \mathrm{br}, 2 \times 8 \mathrm{H}, o, m-$ $\mathrm{Ph})$. Elemental analysis: Calcd. for $\mathrm{C}_{78} \mathrm{H}_{94} \mathrm{~B}_{2} \mathrm{Fe}_{3} \mathrm{Li}_{2} \mathrm{O}_{10}$ (1394.58): C, 67.18; H, 6.79. Found: C, 67.40; H, 6.89\%. Elemental analysis: Calcd. for $\mathrm{C}_{70} \mathrm{H}_{78} \mathrm{~B}_{2} \mathrm{Fe}_{3} \mathrm{LiO}_{8}(1243.43) \times \mathrm{C}_{4} \mathrm{H}_{8} \mathrm{O}$ (72.11): C, 67.56; H, 6.59. Found: $\mathrm{C}, 67.71 ; \mathrm{H}, 6.62 \%$.

Synthesis of Li[11]. Ferrocene $(5.00 \mathrm{~g}, 26.88 \mathrm{mmol})$ was treated with THF $(25 \mathrm{~mL})$ and the mixture cooled to $0{ }^{\circ} \mathrm{C}$. tert-BuLi in pentane $(1.6 \mathrm{M} ; 14 \mathrm{~mL}, 22.4 \mathrm{mmol})$ was added dropwise with stirring to the amber coloured slurry, whereupon the colour changed to red. The reaction mixture was stirred at $0{ }^{\circ} \mathrm{C}$ for another $15 \mathrm{~min}$ and allowed to warm to r. t. $\mathrm{BF}_{3} \cdot \mathrm{OEt}_{2}(0.37 \mathrm{~g}$, $2.61 \mathrm{mmol})$ in THF $(5 \mathrm{~mL})$ was added slowly over a period of $1 \mathrm{~h}$. The mixture was stirred for $15 \mathrm{~h}$, the solvents were removed under vacuum and the residue extracted with $\mathrm{Et}_{2} \mathrm{O}(40 \mathrm{~mL})$. The remaining solid was kept under vacuum overnight to remove residual ferrocene. Single crystals of $\mathrm{Li}(\mathrm{THF})_{4}[\mathbf{1 1}]$ were grown by gas-phase diffusion of pentane into a THF solution of the crude product. Yield of $\mathrm{Li}(\mathrm{THF})_{4}[\mathbf{1 1}]: 0.70 \mathrm{~g}(26 \%)$. ${ }^{11} \mathrm{~B}\left\{{ }^{1} \mathrm{H}\right\}$ NMR (96.3 MHz, $d_{8}$-THF): $\delta-15.3\left(h_{1 / 2}=10 \mathrm{~Hz}\right)$. 'H NMR (300.0 MHz, $d_{8}$-THF): $\delta 3.69\left(\mathrm{~s}, 20 \mathrm{H}, \mathrm{C}_{5} \mathrm{H}_{5}\right), 3.87,4.34(2 \times$ n.r., $\left.2 \times 8 \mathrm{H}, \mathrm{C}_{5} \mathrm{H}_{4}\right) .{ }^{13} \mathrm{C}\left\{{ }^{1} \mathrm{H}\right\}$ NMR $\left(75.5 \mathrm{MHz}, d_{8}\right.$-THF): $\delta 66.0$ (mult, $\left.\mathrm{C}_{5} \mathrm{H}_{4}\right), 68.1\left(\mathrm{C}_{5} \mathrm{H}_{5}\right), 74.7$ (mult, $\left.\mathrm{C}_{5} \mathrm{H}_{4}\right)$, n.o. $(\mathrm{BC})$. Elemental analysis: Calcd. for $\mathrm{C}_{56} \mathrm{H}_{68} \mathrm{BFe}_{4} \mathrm{LiO}_{4}$ (1046.25): $\mathrm{C}, 64.29 ; \mathrm{H}, 6.55$. Found: C, 63.88; H, 6.54\%.

Crystal structure determinations of $3,6,7,(\mathrm{Li}(12-\mathrm{c}-4)(\mathrm{THF}))_{2}[10]$, $\mathrm{Li}(12-\mathrm{c}-4)_{2}[10]$ and $\mathrm{Li}(\mathrm{THF})_{4}[11]$

Single crystals of $3,6,7,(\mathrm{Li}(12-\mathrm{c}-4)(\mathrm{THF}))_{2}[10], \mathrm{Li}(12-\mathrm{c}-4)_{2}[10]$ and $\mathrm{Li}(\mathrm{THF})_{4}[11]$ were analyzed with a STOE IPDS II twocircle diffractometer with graphite-monochromated $\mathrm{MoK}_{\alpha}$ radiation. Empirical absorption corrections were performed using the MULABS ${ }^{36}$ option in PLATON. ${ }^{37}$ The structures were solved by direct methods using the program SHELXS ${ }^{38}$ and refined against $F^{2}$ with full-matrix least-squares techniques using the program SHELXL-97. ${ }^{39}$ All non-hydrogen atoms (except disordered atoms in $\mathrm{Li}(12-\mathrm{c}-4)_{2}$ ) were refined with anisotropic displacement parameters. Hydrogen atoms were refined using a riding model. The crown ether molecules of $(\mathrm{Li}(12-\mathrm{c}-4)(\mathrm{THF}))_{2}[\mathbf{1 0}]$ are disordered over two positions (occupancy factors $0.663(5)$ and $0.337(5)$ ). $\mathrm{Li}(12-\mathrm{c}-4)_{2}[10]$ contains one equivalent of non-coordinating THF in the crystal lattice. One of the two crown ether molecules of $\mathrm{Li}(12-\mathrm{c}-4)_{2}[10]$ is disordered over two positions (occupancy factors
$0.51(1)$ and $0.49(1))$. The Flack-x-parameters for structures 3 and 6 are $0.00(2)$ and $-0.02(3)$, respectively.

CCDC reference numbers: 699649 (3), 699647 (6), 699646 (7), $699650\left((\mathrm{Li}(12-\mathrm{c}-4)(\mathrm{THF}))_{2}[10]\right), 699648\left(\mathrm{Li}(12-\mathrm{c}-4)_{2}[10]\right)$ and $710783\left(\mathrm{Li}(\mathrm{THF})_{4}[11]\right) . \dagger$

Electrochemical measurements. All electrochemical measurements were performed by using an EG\&G Princeton Applied Research $263 \mathrm{~A}$ potentiostat with glassy carbon or platinum disc working electrode. Carefully dried $\left(\mathrm{CaH}_{2}\right)$ and degassed $\mathrm{CH}_{2} \mathrm{Cl}_{2}$ was used as the solvent and $\left[\mathrm{NBu}_{4}\right]\left[\mathrm{PF}_{6}\right]$ as the supporting electrolyte $(0.1 \mathrm{M})$. All potential values are referenced against the $\mathrm{FcH} / \mathrm{FcH}^{+}$couple. Spectroelectrochemical measurements were performed in a home-built optically transparent thin-layer electrolysis (OTTLE) cell following the design of Hartl et al..$^{40}$ with a Bruins Instruments Omega $20 \mathrm{UV} /$ vis/NIR spectrometer.

Mößbauer spectra. The details of ${ }^{57} \mathrm{Fe}$ temperature-dependent Mößbauer spectroscopy have been described earlier. ${ }^{41-43}$ Due to the air- and moisture sensitivity of the compounds, sample transfer to perspex sample holders, lubricated with high-temperature silicone grease and sealed with $\mathrm{O}$-rings, was effected in an inert-atmosphere glove box (VAC model DLX-001-S-P) having an oxygen partial pressure of less than $0.5 \mathrm{ppm}$ and less than $1 \mathrm{ppm} \mathrm{H}_{2} \mathrm{O}$. The filled and sealed sample holders were removed from the glove box, immediately cooled to liquid nitrogen temperature, and then placed into the Mößbauer spectrometer pre-cooled to $\approx 90 \mathrm{~K}$. Data accumulation (in the first instance) was effected in a warming mode as discussed above. All isomer shifts are reported with respect to the centroid of a room temperature $\alpha-\mathrm{Fe}$ absorber spectrum which was also used for spectrometer calibration.

\section{Acknowledgements}

M. W. is grateful to the "Deutsche Forschungsgemeinschaft" (DFG) and the "Fonds der Chemischen Industrie" (FCI) for financial support. L. K. wishes to thank the "Hessisches Ministerium für Wissenschaft und Kunst" for a Ph. D. grant. The authors are also indebted to A. Aharoni for effecting the careful sample transfers in an inert atmosphere glovebox to avoid oxidative degradation prior to spectral examination of the samples referred to herein.

\section{References}

1 I. Manners, Adv. Organomet. Chem., 1995, 37, 131.

2 P. Nguyen, P. Gómez-Elipe and I. Manners, Chem. Rev., 1999, 99, 1515 3 I. Manners, Science, 2001, 294, 1664.

4 I. Manners, Synthetic Metal-Containing Polymers, Wiley-VCH, Weinheim, 2004.

5 D. A. Foucher, B.-Z. Tang and I. Manners, J. Am. Chem. Soc., 1992, 114, 6246.

6 F. Jäkle, R. Rulkens, G. Zech, D. A. Foucher, A. J. Lough and I. Manners, Chem. Eur. J., 1998, 4, 2117.

7 T. J. Peckham, J. A. Massey, C. H. Honeyman and I. Manners Macromolecules, 1999, 32, 2830.

8 R. Rulkens, D. P. Gates, D. Balaishis, J. K. Pudelski, D. F. McIntosh, A. J. Lough and I. Manners, J. Am. Chem. Soc., 1997, 119, 10976.

9 K. Ma, M. Scheibitz, S. Scholz and M. Wagner, J. Organomet. Chem., $2002,652,11$.

10 J. B. Heilmann, M. Scheibitz, Y. Qin, A. Sundararaman, F. Jäkle, T Kretz, M. Bolte, H.-W. Lerner, M. C. Holthausen and M. Wagner, Angew. Chem. Int. Ed., 2006, 45, 920. 
11 J. B. Heilmann, Y. Qin, F. Jäkle, H.-W. Lerner and M. Wagner, Inorg. Chim. Acta, 2006, 359, 4802

12 M. Scheibitz, R. F. Winter, M. Bolte, H.-W. Lerner and M. Wagner, Angew. Chem. Int. Ed., 2003, 42, 924.

13 M. Scheibitz, J. B. Heilmann, R. F. Winter, M. Bolte, J. W. Bats and M. Wagner, Dalton Trans, , 2005, 159.

14 M. Fontani, F. Peters, W. Scherer, W. Wachter, M. Wagner and P. Zanello, Eur. J. Inorg. Chem., 1998, 1453.

15 M. Fontani, F. Peters, W. Scherer, W. Wachter, M. Wagner and P. Zanello, Eur. J. Inorg. Chem., 1998, 2087.

$16 \mathrm{M}$. Grosche, E. Herdtweck, F. Peters and M. Wagner, Organometallics, $1999, \mathbf{1 8}, 4669$

17 R. E. Dinnebier, M. Wagner, F. Peters, K. Shankland and W. I. F. David, Z. Anorg. Allg. Chem., 2000, 626, 1400.

18 M. D. Thomson, M. Novosel, H. G. Roskos, T. Müller, M. Scheibitz, M. Wagner, F. Fabrizi de Biani and P. Zanello, J. Phys. Chem. A., 2004, 108,3281 .

19 D. O. Cowan, P. Shu, F. L. Hedberg, M. Rossi and T. J. Kistenmacher, J. Am. Chem. Soc., 1979, 101, 1304

20 B. Wrackmeyer, U. Dörfler, W. Milius and M. Herberhold, Z. Naturforsch. $B, 1996,51,851$. Note that also the corresponding mesityl derivative $\mathrm{FcBMes} 2$ has recently been published: A. E. J. Broomsgrove, D. A. Addy, C. Bresner, I. A. Fallis, A. L. Thompson and S. Aldridge, Chem. Eur: J., 2008, 14, 7525.

21 R. W. Fish and M. Rosenblum, J. Org. Chem., 1965, 30, 1253.

22 W. Haubold, J. Herdtle, W. Gollinger and W. Einholz, J. Organomet. Chem., 1986, 315, 1 .

23 L. Kaufmann, H. Vitze, M. Bolte, H.-W. Lerner and M. Wagner, Organometallics, 2007, 26, 1771.

24 M. D. Rausch and D. J. Ciappenelli, J. Organomet. Chem., 1967, 10, 127.

25 I. R. Butler, W. R. Cullen, J. Ni and S. J. Rettig, Organometallics, 1985, 4, 2196.

26 H. Nöth and B. Wrackmeyer, Nuclear Magnetic Resonance Spectroscopy of Boron Compounds, in NMR Basic Principles and Progress, ed. P. Diehl, E. Fluck and R. Kosfeld, Springer, Berlin, 1978.
27 A. Appel, F. Jäkle, T. Priermeier, R. Schmid and M. Wagner, Organometallics, 1996, 15, 1188.

28 M. Scheibitz, M. Bolte, J. W. Bats, H.-W. Lerner, I. Nowik, R. H. Herber, A. Krapp, M. Lein, M. C. Holthausen and M. Wagner, Chem. Eur: J., 2005, 11, 584.

29 B. E. Carpenter, W. E. Piers, M. Parvez, G. P. A. Yap and S. J. Rettig, Can. J. Chem., 2001, 79, 857 .

30 B. Wrackmeyer, U. Dörfler, W. Milius and M. Herberhold, Polyhedron, $1995,14,1425$.

31 K. Venkatasubbaiah, I. Nowik, R. H. Herber and F. Jäkle, Chem. Commun., 2007, 2154

32 I. Nowik and R. H. Herber, Eur. J. Inorg. Chem., 2006, 5069.

33 R. H. Herber, I. Nowik, D. A. Loginov, Z. A. Starikova and A. R. Kudinov, Eur. J. Inorg. Chem., 2004, 3476.

34 G. E. Southard and M. D. Curtis, Organometallics, 2001, 20, 508. For detailed studies on IVCT interactions in a 1,2-diborylated ferrocene dimer see: $(a) \mathrm{K}$. Venkatasubbaiah, L. N. Zakharov, W. S. Kassel, A. L. Rheingold and F. Jäkle, Angew. Chem., Int. Ed., 2005, 44, 5428; (b) K. Venkatasubbaiah, A. Doshi, I. Navik, R. H. Herber, A. L. Rheingold and F. Jäkle, Chem.-Eur. J., 14, 444; (c) ref. 31 .

35 F. Rebiere, O. Samuel and H. B. Kagan, Tetrahedron Lett., 1990, 31, 3121 .

36 R. H. Blessing, Acta Cryst., 1995, A51, 33.

37 A. L. Spek, J. Appl. Cryst., 2003, 36, 7.

38 G. M. Sheldrick, Acta Cryst., 1990, A46, 467

39 G. M. Sheldrick, SHELXL-97. A Program for the Refinement of Crystal Structures, Universität Göttingen, 1997.

40 M. Krejčik, M. Daněk and F. Hartl, J. Electroanal. Chem., 1991, 317, 179

41 I. Nowik and R. H. Herber, Inorg. Chim. Acta, 2000, 310, 191.

42 R. H. Herber and I. Nowik, Hyperfine Interact., 2000, 126, 127.

43 R. H. Herber and I. Nowik, Hyperfine Interact., 2001, 136/137, 699. 